\title{
ANÁLISES E DISCUSSÕES SOBRE O DIREITO À MORADIA ADEQUADA NO BRASIL: EM FOCO A CIDADE DE ARAGUAÍNA - TO
}

\author{
ANALYSIS AND DISCUSSION ON THE RIGHT TO ADEQUATE HOUSING IN BRAZIL: IN \\ FOCUS ARAGUAINA CITY - TO.
}

\author{
João Manoel Vasconcelos Filho ${ }^{1}$
}

\section{Resumo}

O objetivo deste estudo é compreender o direito à moradia na cidade de Araguaína-TO. Adentramos na discussão do direito à moradia adequada, projeto estabelecido pela Organização das Nações Unidas - ONU, que acompanha em escala global, como vem sendo tratado o problema da moradia para os mais pobres, com a finalidade de compreender o que este organismo considera direito à moradia adequada. Somou-se a isto a inserção dos princípios norteadores das cidades saudáveis, evidenciando mais uma vez a necessidade de refletir em conjunto a moradia e a cidade. Para entendermos melhor as particularidades das áreas de moradia social em Araguaína, percorremos todos os setores da cidade que abrigam essas políticas públicas. Ao fazer esta incursão no urbano pudemos compreender melhor à cidade e sua realidade urbana. Isto possibilitou ainda a aplicação de formulários de pesquisa no Residencial Jardim das Flores, uma vez que das áreas de política pública, é o que apresenta a melhor infraestrutura, mas que também apresenta muitos problemas. Araguaína foi e continua sendo um grande desafio, notadamente no que diz respeito ao direito à moradia adequada. Assim constatamos que a produção do espaço urbano e da moradia ocorrem a um tempo sob um quadro de precariedade expoente.

Palavras-chaves: Moradia, Cidade, Direito

\begin{abstract}
The objective of this study is to understand the right to housing in the city of Araguaína-TO. We enter the discussion of the right to adequate housing, the project established by the United Nations - UN, which tracks on a global scale, how has been dealt the problem of housing for the poorest, in order to understand what this institution considers the right to adequate housing. Added to this is the inclusion of the guiding principles of healthy cities, emphasizing once again the need to reflect together the housing and the city. To better understand the particularities of the areas of social housing in Araguaína, we go through all sectors of the city that are home to those policies. By doing this foray into the city, we could better understand the city and its urban reality. This also enabled the application of survey forms in the Residential Garden of Flowers, since the public policy areas, is the one with the best infrastructure, but also raises many problems. Araguaína was and remains a major challenge, especially with regard to the right to adequate housing. Thus, we find that the production of urban space and housing has been occurring for a time under an exponent precarious frame.
\end{abstract}

Keywords: House, City, Law

\footnotetext{
${ }^{1}$ Doutor em Geografia pela Universidade Federal de Uberlândia, com Estágio Doutoral na Universidade de Lisboa. Professor adjunto da Universidade Federal do Rio Grande do Norte. E-mail: vasconfilho@gmail.com
} 


\section{INTRODUÇÃO}

A moradia no Brasil ainda é um tema que exige muitos estudos e, portanto, análises e reflexões. São muitos contextos sociais, políticos e econômicos em que a moradia se insere, se configurando enquanto uma problemática a ser superada. Se por um lado há muito conhecimento acumulado e sistematizado em algumas porções deste território, por outro, há uma lacuna considerável em espaços ainda pouco conhecidos, onde o processo de urbanização é surpreendentemente incompleto e porque não dizer ausente, que é o caso de Araguaína. Daí vem à escolha por estudar essa cidade, onde não se registrava até o momento desse estudo, algum tipo de pesquisa sobre a temática em tela. Assim, a cidade de Araguaína, norte do estado do Tocantins, é testemunho e lócus deste estudo.

Portanto, o objetivo desta pesquisa é compreender e refletir sobre o direito à moradia na cidade de Araguaína. Entretanto, entendemos que essa compreensão/reflexão só foi possível quando esse direito foi contextualizado com o direito à cidade. A proposta deste estudo põe em evidência questões que vão muito além do déficit habitacional, ou seja, da escassez da moradia em si. Pensamos assim, porque acreditamos que para além das estatísticas, estão as histórias de vida dos atores sociais, estão às cotidianidades construídas, expressas nas relações complexas com o espaço. Quanto a estes fatores, as estatísticas não contam. Esta é uma das preocupações deste estudo.

Para este feito, adentramos na discussão do direito à moradia adequada, projeto estabelecido pela ONU que acompanha em escala global como vem sendo tratado o problema da moradia para os mais pobres. Somou-se a isto a inserção dos princípios norteadores das cidades saudáveis. A ideia do movimento cidade saudável tem início com uma conferência de promoção à saúde realizada em 1986, na cidade de Ottawa, Canadá, resultando na construção de um documento conhecido por "Carta de Ottawa. " A base para a construção do que pode vir a ser uma cidade saudável, ou seja, desse movimento que fala sobre a saúde das pessoas e, portanto, a saúde das cidades está no centro dessas discussões que foram proferidas na Primeira Conferência Internacional sobre a Promoção da Saúde, realizada na cidade de Ottawa, Canadá.

A "Carta de Ottawa" estabelece que a concretização dos princípios que regem a saúde do indivíduo encontra-se articulada com uma série de outros fatores que vão muito além da pessoa em si. Por exemplo, as condições de saúde de cada pessoa estão inter-relacionada com o espaço onde ela vive, com as condições de trabalho, com o lazer, com os modelos de gestão de cada 
município, com sua moradia e finalmente com o acesso a um certo padrão alimentar. "Paz, Habitação, Educação, Alimentação, Renda, ecossistema estável, recursos sustentáveis, justiça social e equidade" (Carta de Ottawa, 1986, p.1)

Tudo isto reforça mais uma vez a necessidade de refletir em conjunto a moradia e a cidade. Posteriormente tratamos de entender as particularidades das áreas de moradia social em Araguaína. Percorremos para isto todos os setores da cidade que abrigam essas políticas públicas. Ao fazer esta incursão no urbano pudemos compreender melhor a cidade e sua realidade urbana.

Araguaína foi e continua sendo um grande desafio. Quando se reveste de um referencial teórico-metodológico que tenta responder aquilo que se percebe no cotidiano, tem-se a nítida impressão que nesta cidade as teorias que envolvem o urbano ainda não são suficientes devido às especificidades de um espaço urbano amplamente deteriorado, que se amplia numa velocidade impressionante, sem cumprimento das normas básicas que regimentam a produção do espaço da cidade. Assim, constatamos que as condições que dão possibilidades ao aumento do preço da terra urbana e seus componentes, a exemplo da moradia, não dependem de amenidades naturais ou produzidas pelo homem, nem de localização.

Como resultado dessas análises e reflexões, há uma necessidade imperativa de compreendermos esse conjunto de relações que se estabelecem pelo movimento contraditório que é permeado pelo capital, colocando em evidência o direito à moradia e o direito à cidade. Seguindo esta direção, fomos impulsionados também pela necessidade de um claro entendimento das contradições socioespaciais.

Por fim o leitor perceberá a busca do entendimento entre o quadro de vida desses grupos e as instituições políticas e econômicas (Estado e Mercado). Para este feito, tornamos evidente que os conflitos surgidos cotidianamente no espaço urbano em Araguaína e no Brasil como um todo é fruto da seletividade criada para a aquisição da terra urbana e, por seu turno, para a moradia. Tudo isto tem sido reproduzido e regido pelos princípios capitalistas norteadores da propriedade privada da terra.

Para construirmos esta investigação científica realizamos um reconhecimento de todos os setores da cidade que receberam na perspectiva espaço-temporal, políticas públicas de moradia social. Trata-se de um trabalho empírico exaustivo, uma vez que o município não dispõe destes dados. Assim, este feito foi realizado literalmente a partir do reconhecimento de cada setor que pudesse abrigar tais políticas. Esta atividade resultou na criação de um quadro de políticas públicas habitacionais, com suas devidas localizações, quantidade de unidades produzidas, área de cada 
moradia, e os principais equipamentos urbanos presentes em cada setor que recebeu as políticas de moradia social.

Em um segundo momento, realizamos um levantamento do perímetro urbano de Araguaína, tomando como base os setores e loteamentos que se encontram com seus registros aprovados pela Prefeitura Municipal, especificamente na Secretaria de Planejamento do Município. Por fim, aplicamos formulários de pesquisa contendo questões direcionadas e contextualizadas com a temática do direito à cidade e à moradia, na perspectiva de cidades saudáveis e democráticas, como também se preocupou em abordar o direito à moradia adequada. Além destes procedimentos, os diálogos mantidos em órgãos governamentais, a exemplo da Secretaria Municipal de Habitação, do Instituto Brasileiro de Geografia e Estatística e da Caixa Econômica Federal, foram promissores, mesmo considerando algumas carências informacionais.

\section{A MORADIA ADEQUADA SEGUNDO OS DIREITOS ESTABELECIDOS PELAS NAÇÕES UNIDAS}

Entender moradia adequada na visão da Organização das Nações Unidas - ONU é constatar o respeito aos direitos que esse órgão chama de Dhesc, que significa Direitos humanos, econômicos, sociais e culturais. Ao fazermos a leitura do relatório que foi realizado no intuito de demonstrar como vem sendo produzida a moradia para os grupos socialmente excluídos da sociedade brasileira, percebemos uma relação de proximidade no que diz respeito aos princípios norteadores do movimento cidades saudáveis.

Entende-se segundo a filosofia da relatoria da ONU que moradia adequada extrapola o espaço físico dela, ou seja, a sua tipologia é apenas uma parte do que se considera adequado e propício a constituição de um verdadeiro ambiente familiar no momento que estão interrelacionados e inseridos em um contexto mais amplo com os vários direitos humanos. A ideia de moradia adequada está associada tanto a um padrão de vida adequado quando à qualidade de vida que uma família precisa para viver de maneira satisfatória.

O núcleo básico da ONU define como Moradia Adequada aquela que apresenta como componentes essenciais: a Segurança jurídica da posse, a disponibilidade de serviços e infraestrutura, custo acessível da moradia, habitabilidade, acessibilidade, localização e adequação cultural. (SAULE JUNIOR \& MENEZES, 2005, p.22)

Assim, mesmo que os Relatores da ONU não façam alusão ao termo cidade saudável, refletimos ser impossível pensar uma moradia adequada sem esses direitos elencados acima. 
Entretanto, é importante destacar que, regra geral, as cidades brasileiras pela sua estrutura física e social, organizadas, ordenadas e pensadas pela ótica do mercado, negam veementemente esses direitos que, acima de tudo, são essenciais a uma vida com dignidade. Entendendo desse modo, foi que sentimos a necessidade de discutir num primeiro momento o direito à moradia adequada e, posteriormente, refletir sobre o que propõe os pensadores do movimento cidades saudáveis.

Como resultado de décadas de carências de políticas públicas urbanas, a problemática social nas cidades brasileiras alcançou níveis alarmantes. No início do século atual os problemas se intensificaram, tornando-se uma constante os registros de conflitos pela aquisição da terra urbana, e por seu turno, do acesso à uma moradia adequada. É oportuno salientar que apesar dos dados oficiais demonstrarem uma sensível queda dos índices de pobreza e miséria no país, a questão da inserção dos grupos sociais excluídos a uma moradia considerada adequada, não tem sido de fato resolvida.

Em tempos mais recentes a visita da Relatoria Especial da Organização das Nações Unidas para Moradia Adequada, verifica que um dos graves problemas que causa um entrave a política habitacional brasileira resulta da falta de compromisso do Estado brasileiro em resolver os questionamentos que cerceiam a estrutura fundiária, que, diga-se de passagem, é tão conservadora e se estabelece praticamente com as mesmas premissas dos colonizadores portugueses, que chegaram neste território no século XV.

Em outubro de 2002, o Conselho de Escolha dos Relatores em DhESC elegeu Relatores Nacionais em seis áreas temáticas consideradas estratégicas: Direito Humano ao Meio Ambiente, à Saúde, à Educação, ao Trabalho, à Alimentação, Água e Terra Rural e a Moradia e Terra Urbana. [...] (SAULE JUNIOR \& MENEZES, 2005, p.10)

No ano de 2004, o Brasil recebeu a Relatoria Especial da Organização das Nações Unidas ONU para a Moradia Adequada. Esta visita teve o objetivo de construir um relatório que observa e analisa como a moradia vem sendo tratada no Brasil, tendo como perspectiva os direitos humanos, as legislações e as políticas públicas do Estado brasileiro, com ênfase no direito à moradia adequada, entendida em seu conceito amplo. Esse trabalho resultou numa publicação organizada por Saule Júnior (2005) e Cardoso (2005), intitulado "o direito à moradia no Brasil: violações, práticas positivas e recomendações ao governo brasileiro".

O trabalho desenvolvido pela Relatoria Especial da ONU para a Moradia Adequada teve o apoio e ampla participação de uma Comissão Nacional, trata-se de um projeto de Relatores Nacionais da plataforma dos Direitos Humanos, Econômicos, Sociais e Culturais - DhESC, constituída por várias organizações da sociedade brasileira, como também pelos movimentos 
sociais, que em conjunto, atuam no campo da defesa dos direitos humanos e na promoção de políticas públicas e sociais voltadas a combater as desigualdades sociais e realizar inclusão social e cultural de grupos sociais historicamente excluídos ou incluídos marginalmente na sociedade. 0 corpo de Relatores Nacionais em defesa dos DhESC construiu seus objetivos fundamentados em:

Receber denúncias de violações do Direito à moradia, Realizar missões in loco para investigar situações de violação do Direito à moradia, Monitorar casos emblemáticos para implementar o Direito à moradia no Brasil, Fornecer subsídios para que se busquem soluções dirigidas, Elaborar relatórios anuais com recomendações ao governo e sociedade brasileira, para garantir o Direito à Moradia no Brasil, Identificar experiências positivas de implementação do Direito à Moradia, Verificar a situação do Direito à Moradia e o acesso aos serviços públicos essenciais e Verificar casos de despejos e deslocamento forçado de populações. (SAULE JUNIOR \& MENEZES, 2005, p.11)

Sem deslegitimar os trabalhos desenvolvidos pela Relatoria Nacional do Direito à Moradia Adequada, destaca-se aqui que o Estado brasileiro, em face de suas dimensões territoriais possui casos tão emblemáticos quanto, ou mais, dos que foram considerados e estudados pelas missões da ONU. Para se ter uma ideia desta questão, a região Norte do Brasil é apenas citada como um estudo das cidades da Amazônia, mas não houve pelo que consta no documento nenhuma visita ou missão a referida região. Por exemplo, nenhuma cidade do Tocantins foi visitada ou se quer mencionada. O levantamento dos problemas habitacionais ficou basicamente circunscrito aos grandes centros urbanos do país. As missões, portanto, contemplaram as cidades de São Paulo, Fortaleza, Salvador, Recife e Alcântara. Houve uma audiência pública em Brasília e os relatos de visitas ao Rio de Janeiro, Bertioga e Guarulhos.

Seria preciso estender as missões a outras porções do território brasileiro para se ter uma dimensão mais realista da problemática enfrentada. Entendendo que cada cidade, cada lugar possui suas especificidades que the atribuem particularidades a determinados problemas. Assim, a política habitacional deverá atender as nuances diferenciadas de cada local. O problema é o mesmo, mas as soluções são diferenciadas.

A par destas contradições, a ONU considera moradia adequada um espaço de vivência onde devem ser respeitados outros direitos que vão além dos limites da moradia, convergindo sobremaneira para o "direito à cidade e outros direitos como os culturais, sociais, econômicos e urbanísticos, dentre outros." (SAULE JÚNIOR \& MENEZES, 2005, p.7). Aqui já se encontram algumas relações com o movimento cidade saudável, que entende a saúde como um aspecto resultante das relações entre as pessoas da cidade e o seu espaço de vivência. Na escala mundial os DhESC são protegidos por tratados internacionais dos quais o Estado brasileiro é signatário. 
Entende-se segundo a filosofia da relatoria da ONU que moradia adequada extrapola o espaço físico dela, ou seja, a sua tipologia é apenas uma parte do que se considera adequado e propício a constituição de um verdadeiro ambiente familiar no momento que estão interrelacionados e inseridos em um contexto mais amplo com os vários direitos humanos. A ideia de moradia adequada está associada tanto a um padrão de vida adequado quando a qualidade de vida que uma família precisa para viver de maneira satisfatória.

Percebe-se ainda que a concepção da ONU, no que tange a moradia adequada estabelece um laço mais coeso entre a moradia e a cidade, entre a família e a sociedade de uma maneira geral. Ao propor que moradia adequada deve ser aquela em que a família está contextualizada com uma ideia de cidade mais participativa sob a perspectiva social e também mais justa. Acrescentase, portanto, que este modelo de pensar e refletir sobre a moradia adequada caminha para outros referenciais que se estende a ideia de construção de uma cidade democrática e saudável.

$\mathrm{Na}$ verdade, entende-se que os princípios norteadores de uma cidade saudável, estão inseridos no contexto de uma moradia adequada e que por seu turno convergem para uma cidade democrática como prega a carta mundial do direito à cidade. Todas essas premissas foram confrontadas na perspectiva do lugar quando realizamos as entrevistas a campo possibilitando o conhecimento da realidade que vive alguns moradores de conjuntos habitacionais de AraguaínaTO. A escolha, para a aplicação de formulários de pesquisa teve como base a realidade dos referenciais que norteiam o direito à moradia adequada e os princípios norteadores da cidade saudável.

Nos vários relatos registrados pela equipe da ONU ficou claro que o desrespeito aos DhESC por parte do Estado, em suas mais variadas instâncias, bem como pelos promotores imobiliários e empresas, que participam e promovem a produção do espaço urbano, tornou-se uma constante, já faz parte da história da sociedade brasileira, notadamente para as populações mais carentes. Quando se discute que as parcelas mais pobres dessa sociedade vivem esse cotidiano de desrespeito é porque os estratos sociais mais vulneráveis inserem-se num momento de insustentabilidade social, ou seja, as degradações sociais e morais permeiam a história de vida desses grupos.

Uma das questões que se põe em evidência é a falta de um diálogo entre os governos e os movimentos sociais envolvidos com os conflitos urbanos por moradia, regra geral, não existe um discurso participativo em que os desejos e necessidades desses grupos sociais mais carentes possam ser ouvidos. As políticas, os projetos habitacionais e de infraestrutura urbana já chegam 
prontos sem ter a devida participação da sociedade local. Este é mais um problema constatado pela Relatoria da ONU, a necessidade da participação ativa dessa sociedade nos diversos programas governamentais.

Outra situação que se torna latente e que não tem sido dada a devida atenção é a plena regularização fundiária das áreas destinadas a tais políticas habitacionais. Afirmamos que este é o fundamento do problema, a questão que se julga aqui proeminente, e que poucos discutem pelo nível de profundidade e complexidade que a problemática expressa. Trata-se da propriedade privada da terra urbana e de a mesma cumprir uma função social e não atender os interesses do mercado, como se tem constatado.

A questão do direito à propriedade privada da terra nas relações capitalistas de produção e de trabalho e a noção de propriedade como um dos instrumentos de produção e de reprodução da força de trabalho, bem como sua alienação deve ser amplamente discutida se a proposta é o entendimento do pano de fundo da questão que envolve o direito à moradia adequada, bem como a produção de cidades saudáveis e democráticas. A discussão é antiga. Desde suas origens, a instituição desse direito à propriedade, para muitos pensadores, a exemplo de Rousseau (2007), é entendida como um pressuposto da origem da desigualdade entre os homens.

A interessante análise do pensador é oportuna e salutar para desvendarmos e arejarmos as noções, as análises e reflexões, ou seja, o pensar sobre a cidade e de sua construção, no que diz respeito aos direitos, essencialmente o direito à moradia adequada, por conseguinte, o direito à cidade na perspectiva de se construir cidades saudáveis. Rousseau (2007) em sua análise sobre a origem da desigualdade do homem apresenta dois modelos de desigualdades, uma de ordem natural, relacionada à condição inerente a cada indivíduo estabelecida e determinada por sua natureza humana. Outro de ordem social, ou seja, produzido e instituído pelo homem em sua condição social, logo diz respeito à sociedade. Sobre essa última, ele assinala.

A outra, que se pode chamar de desigualdade moral ou política, porque depende de uma espécie de convenção, e que é estabelecida ou pelo menos utilizada pelo consentimento dos homens. Consiste está nos diferentes privilégios de que gozam alguns com prejuízo dos outros, como ser mais ricos, mais honrados, mais poderosos do que os outros, ou mesmo fazeremse obedecer por eles. (ROSSEAU, 2007, p.31)

No pensamento de Rousseau (2007) nota-se que a desigualdade social foi convencionalmente criada pelo homem. Uma forma de estabelecer diferenças que culmina com privilégios de uns em detrimento de outros. Uma maneira de submeter um grupo as ordens de outro, produzindo assim os que obedecem e os que mandam a partir de critérios e convenções. 
Não obstante, observa-se nas palavras de Rousseau uma ausência clara do entendimento da ordem que advém do modo de produção capitalista, onde tais convenções, apesar de não ter sido criada pelo modo de produção vigente, tornaram-se regras, modelos a serem seguidos por todas as sociedades, mesmo aquelas que se arrogam no direito de se considerar socialistas.

Destarte, entende-se que a submissão social de um grupo em relação ao outro é criada, reproduzido e efetivado no imaginário social, onde ganha materialidade. O referido pensador vai buscar subsídio para explicar essas constatações no direito à propriedade como um pressuposto que concretiza e aprofunda tais desigualdades. Logo, é no direito à propriedade que se manifesta as mais variadas formas de desigualdade social que se aprofunda nos dias de hoje, relacionando-se assim, com uma múltipla negação dos direitos, notadamente, o direito à moradia adequada e a possibilidade de produção de cidades saudáveis. As origens e os males salientados por Rousseau, a partir da instituição social do direito à propriedade são reveladores dos males sociais que se avultam no momento contemporâneo.

O primeiro tendo cercado um terreno se lembrou de dizer: Isto é meu, e encontrou pessoas bastantes simples para o acreditar, foi o verdadeiro fundador da sociedade civil. Quantos crimes, guerras e assassínios, misérias e horrores não teria poupado ao gênero humano aquele que arrancando as estacas ou tapando os buracos, tivesse gritado aos seus semelhantes: "Livrainos de escutar esse impostor; estarei perdido se esquecerdes que os frutos são de todos, e a terra de ninguém!" (ROSSEAU, 2007, p.61)

Com se podem constatar, as análises instituídas pelo filósofo, apesar de ter sido produzida em 1755, ou seja, na véspera da Revolução Francesa, são emblemáticas para discutirmos as disfunções originadas pelas desigualdades sociais neste momento. Tal análise atravessou os séculos, e nunca esteve tão contemporânea no sentido de ser utilizada como reflexão dos problemas urbanos que se afiguram nos dias de hoje.

Entretanto, é preciso compreender as demandas capitalistas desse estágio atual, onde o modo de produção sofre profunda crise que na verdade o alimenta, traz energia, onde ele se fortifica. Basta observar que a origem da crise do capitalismo pelo qual o mundo ainda está passando tem fundamentos na crise do capital imobiliário americano que provocou uma reação em cadeia dos mercados em todo o mundo.

Toda essa problemática gerada com a crise imobiliária provocou uma reviravolta, abalando as estruturas dos mercados mundiais, em economias, ricas, emergentes e pobres. Certamente, essa crise provocou desestruturação e desequilíbrio social, culminando na intensificação dos 
problemas urbanos, notadamente, aqueles relativos à produção de moradias para as classes populares.

O capital financeiro que sustenta o mercado e o próprio mercado se mostraram frágeis, necessitando da atuação, da intervenção dos Estados justamente naqueles países, que criaram a ideia de uma sociedade conduzida e governada pelo mercado e seu atributo mais difundido, qual seja, a flexibilidade. Todo esse discurso caiu por terra, atingindo de forma dramática a sociedade global. Esse é também o momento oportuno de revisitar conceitos e concepções, revendo normas e valores criados e instituídos pelo capitalismo, é uma das fases mais promissoras das ciências sociais.

Pelo exposto é possível entender com mais nitidez a visão e a assimilação que o mercado imobiliário imprime a moradia popular, algo que ganha respaldo perante o Estado. Trazendo essa discussão para o direito à moradia adequada e a possibilidade de existência do direito às cidades saudáveis, em seu sentido amplo, percebe-se a necessidade de se fazer profundas mudanças. Os teóricos acima, à exceção de Marx, ao discutir o valor e a mercadoria não evidenciam um componente cuja preocupação seja o social. Logo ao se discutir a produção de moradia no momento atual, isto não é assimilado como um componente social necessário a vida, e tampouco como um valor de uso, mas nitidamente como um valor de troca a partir do pressuposto do lucro que a retenção e a propriedade da terra urbana podem proporcionar.

É, portanto, a partir da lógica e da premissa da propriedade privada da terra urbana que se discute moradia no Brasil, e não a partir de um direito presente na Constituição Federal. Portanto, o que está em jogo é quantidade de lucros auferidos pelas empresas imobiliárias, reporta-se aqui, as construtoras, incorporadoras e imobiliárias que instituem seus interesses na produção do espaço e da terra urbanas, usando diversas estratégias, como a retenção da terra urbana para especulação. Daí porque não há de fato mudanças substanciais na estrutura fundiária da terra urbana.

Outra questão discutida pela Relatoria Especial da ONU sobre o direito à moradia adequada foi o despreparo, a falta de informação e o desinteresse por parte do corpo de juízes no Brasil que se quer conhece o Estatuto da Cidade, e muito menos da política habitacional presente nesse documento. A maioria das causas presentes nas varas cíveis é ganha pelos que se dizem proprietários das terras, muitas vezes por grilagem de terras urbanas, mas que tem seus interesses garantidos por um corpo jurídico que se apega ao princípio inelutável do sagrado direito da propriedade. 
Tais interpretações da Lei têm gerado e intensificado os conflitos pela aquisição da terra urbana e pelo acesso à moradia. O que está em pauta é um conjunto de interesses instituídos e garantidos pela justiça, sob o poder que emana do mercado, que contempla em sua maioria, aquelas que detêm grandes parcelas de terra urbana, ou seja, as elites desse país. Não é de se estranhar que as ordens de despejos e reintegração de posse, em vários compartimentos da cidade, façam parte do cotidiano dos grupos de vulnerabilidade social, que, como qualquer outro indivíduo, necessita de um lugar para morar bem.

Se a casa e a terra urbana, para as classes mais pobres, continuarem a ser vista sob perspectiva de aumento de lucros pelos promotores imobiliários e mesmo pelo o Estado, o déficit habitacional, no âmbito do território brasileiro, está muito longe de ser solucionado, assim como a produção de moradia adequada em lugares adequados. A questão que se coloca como preocupante é atender os interesses do mercado em prejuízo dos interesses do cidadão. Nos muitos relatos ouvidos pela ONU, em sua missão pelo país, tem-se o registro de um representante de uma área de conflito o Sr. Antonio José, do Movimento Nacional de Luta pela Moradia - MNLM, onde o mesmo relata.

Ainda é muito presente na discussão da moradia a questão de " $x$ " e " $y$ " salários mínimos. Quando você relaciona o custo da moradia às condições daquela família que vai obtê-la, você não está considerando muito a moradia como direito fundamental, mas como uma mercadoria pela qual, em maior ou menor valor, as pessoas ainda têm que pagar. (Antônio José, 2004, p. 38. Entrevista concedida à Relatoria da ONU)

A fala do representante do MNLM é relevante e reafirma a trajetória dessa discussão, pois é preciso entender a questão a partir dos atores sociais, excluídos, marginalizados pelo modelo de produção que opera no Brasil e não a partir do custo e benefício para o mercado. Esta reflexão tem respaldo no instante em que se entende que o Estado brasileiro possui instrumentos necessários a promover uma profunda transformação na implementação das políticas públicas urbanas, notadamente as que estão voltadas para a habitação de interesse social.

Não obstante, tem se constatado uma crescente mercantilização na filosofia da construção dessas políticas nesse país. Apesar da implantação do Programa Minha Casa, Minha Vida, os direitos do mercado tem se sobreposto aos direitos do cidadão. Basta perceber a qualidade dessas moradias e os lugares onde estão sendo produzidas, regra geral, são distantes da Área Central da cidade e em muitos casos em compartimentos da cidade que trazem riscos à saúde dos mais pobres. Além disto, essas moradias e os que nelas habitam estão muito longe do acesso aos serviços básicos de saúde e educação, bem como do próprio local de trabalho. É necessário criar 
também um discurso de obrigação e não apenas de direitos. Pois se entende que é obrigação do Estado promover o bem-estar da sociedade, em diversos aspectos da vida.

Com efeito, como pensar em sustentabilidade social e a construção de cidades saudáveis em seu sentido amplo se não resolvermos essas contradições que dão fundamento a problemática exposta e que aqui se entende como a raiz do problema? Sob este prisma, em todos os relatos constatados pela ONU, os grupos sociais mais pobres se encontram numa situação de extremo risco à saúde e, portanto, à vida, principalmente as crianças.

É fácil constatar esse problema, pois as áreas ocupadas pelas famílias sem teto estão à beira de córregos e rios ou em áreas arenosas do Cerrado, como é o caso de Araguaína, registrado nas figuras 1 e 2 .

Figura 1: Araguaína: Área de política pública habitacional. Avenida Itamarati, Setor Universitário.

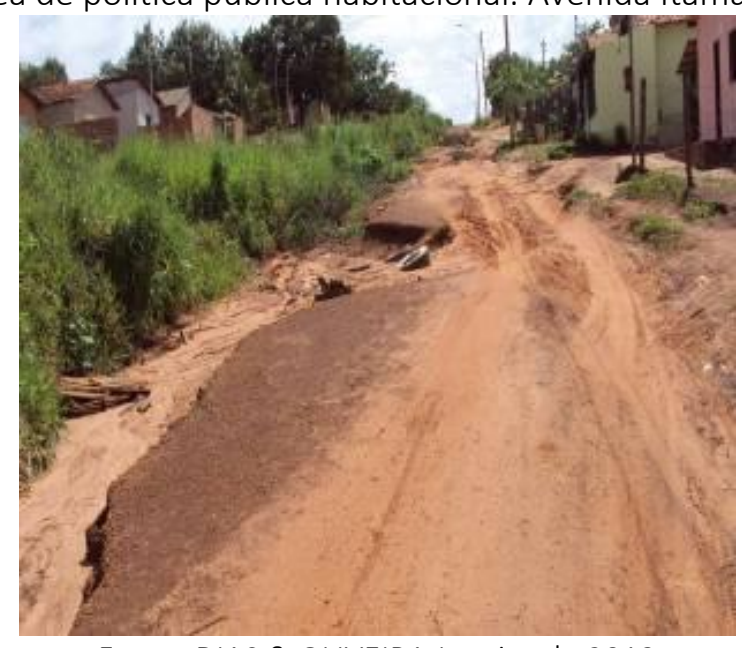

Fonte: DIAS \& OLIVEIRA Janeiro de 2013

Figura 2: Araguaína: Outro trecho da Avenida Itamarati no setor Universitário.

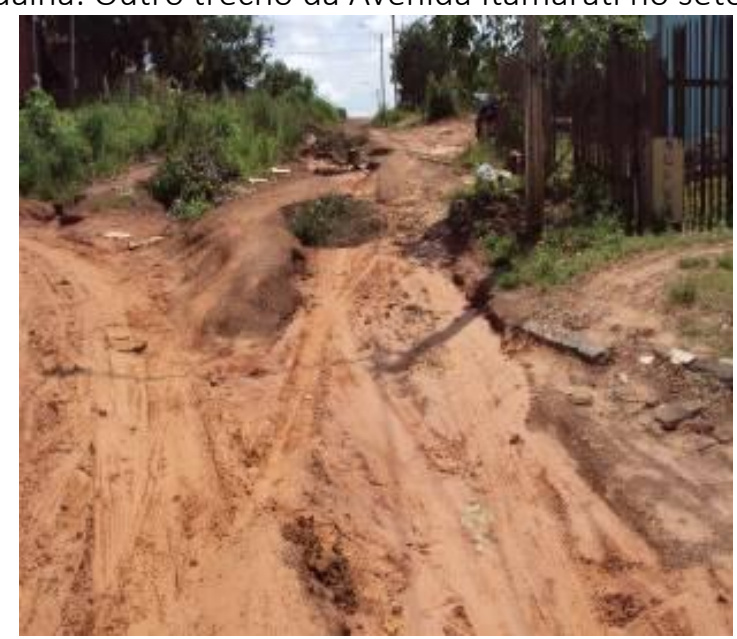

Fonte: DIAS \& OLIVEIRA Janeiro de 2013 
Além da questão exposta, não apenas do ambiente em si que esses grupos ocupam, pois são insalubres, mas o próprio padrão de habitabilidade dessas populações que não têm acesso a água potável, ao saneamento ambiental e a um conjunto de equipamentos e serviços públicos tais como: posto de saúde, escolas, creches, transporte coletivo, lazer e cultura, dentre outros. $\mathrm{Na}$ verdade, faltam-Ihes quase tudo. Esta é a situação de quem vive nas favelas e cortiços espalhados em todos os pontos do espaço urbano brasileiro. O relato abaixo expressa um pouco dessa situação.

É muito duro morar em cortiço como eu morei. A minha filha teve uma bronquite muito forte e até hoje tem problema. As crianças também têm problemas de saúde, são crianças com problemas respiratórios, não tem sol, não têm vento, vivem em condições subumanas. Aqui no centro da cidade é o 20 índice de mortalidade infantil. (VERÔNIKA KROLL, 2004, p.32)

Como se pode constatar os testemunhos de uma vida decadente, marginalizada, assolada, por doenças, medo, miséria e todo corolário de violência a que estas famílias estão sujeitas é de impressionar. Entretanto, ao se tornar cenas comuns de uma cidade e de uma sociedade que clama por mais justiça social, os governos preferem "maquiar" o problema ao invés de resolvê-los. A política urbana presente no Estatuto da Cidade nos termos do artigo 2, incisos I e II, é claro quando afirma:

A política urbana tem por objetivo ordenar o pleno desenvolvimento das funções sociais da cidade e da propriedade urbana, mediante as seguintes diretrizes gerais. "I - garantia do direito a cidades sustentáveis, entendido como o direito à terra urbana, à moradia, ao saneamento ambiental, à infraestrutura urbana, ao transporte e aos serviços públicos, ao trabalho e ao lazer, para as presentes e futuras gerações. (ESTATUTO DA CIDADE, 2001, p.13)

É importante destacar que a ONU, não criminaliza as invasões quando estas ocorrem por legítima necessidade das famílias e quando o Estado não cumpre seu papel no que diz respeito ao desenvolvimento de políticas públicas de moradia social para os grupos histórico e espacialmente excluídos da sociedade. Segundo as palavras do relator Miloon Kothari, que esteve em visita ao Brasil em 2004, invasões de áreas públicas e privadas são "legítimas" e consistente com a luta pelos direitos humanos quando os governos não têm respondido as reivindicações da população e garantido condições adequadas de habitação para todo mundo. " (KOTHARI, 2004, apud SAULE JUNIOR \& MENEZES, 2005, p. 141)

Alguns pressupostos são estabelecidos pela Relatoria Nacional, em conformidade com o que estabelece a ONU no que diz respeito à moradia adequada, no sentido de encaminhar algumas diretrizes para a solução de conflitos pela posse da terra e da moradia, principalmente quando se 
constata que os grupos sociais vulneráveis estão sujeitos a um cotidiano de despejos e de ameaças de deslocamentos forçados em face das decisões judiciais que, regra geral, aponta para a retomada da posse da terra, como se pode constatar nas figuras 3 e 4, um despejo ocorrido em Araguaína, em 2010. Tais pressupostos visam uma solução pacífica para esses enfrentamentos, seguindo estas recomendações.

Figura 3: Araguaína: Resultado do despejo das famílias na "Vila Maranhão"

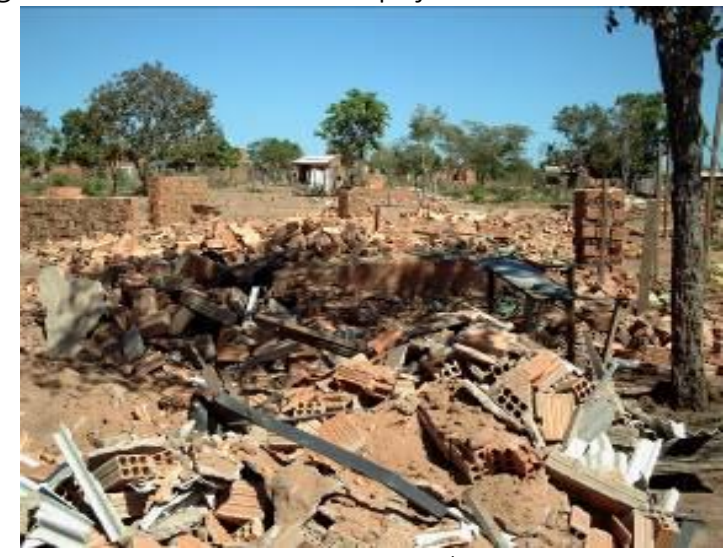

Fonte: Vasconcelos Filho/julho de 2010

Figura 4: Araguaína: Restos das moradias após a demolição e despejo das famílias na "Vila

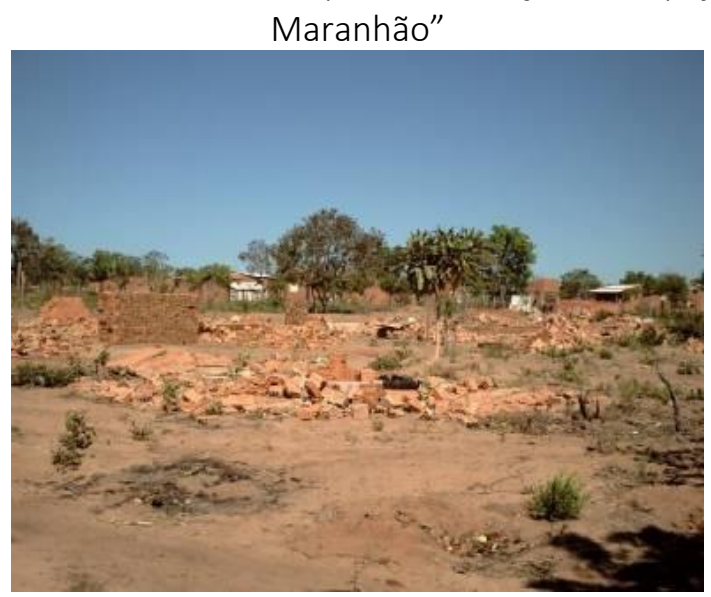

Fonte: Vasconcelos Filho/julho de 2010

Estas recomendações seguem as orientações da Constituição Brasileira, do Estatuto da Cidade, da Organização Internacional do Trabalho - OIT e da Convenção de Genebra de 1949, Protocolos de 1977 e a Convenção 169/OIT, regulamentado pelo Decreto no 5.051 de 19 de abril de 2004. 
1. Reconhecer os grupos vulneráveis como titulares do Direito à Moradia;

2. Democratizar o acesso à terra e à propriedade;

3. Reconhecer e fazer valer o direito à participação;

4. Disseminar informações que ajudem a todos;

5. Regulamentar devidamente a proteção legal às pessoas afetadas pelas ações de remoção, realocação, despejo;

6. Garantir a proteção processual das pessoas afetadas pelos despejos forçados;

7. Respeitar as populações tradicionais e seus modos de vida. (SAULE JUNIOR \& MENEZES, 2005, p. 142)

Além das diretrizes estabelecidas pela ONU para uma solução pacífica dos conflitos que se tornaram cenas comuns nas cidades brasileiras de uma maneira, geral, incluindo aqui a cidade de Araguaína-TO, recomenda-se e lembra-se também do papel que deve exercer o Estado no momento desta problemática. Muito embora, esta instituição política tem recuado diante dos vários problemas que surgem no cotidiano urbano das cidades brasileiras.

Mas as determinações são claras quanto ao papel do Estado quando se afirma no inciso I do item 14 do Comentário Geral no 7 do Comitê dos Direitos Econômicos, Sociais e Culturais das Nações Unidas, que "antes de realizar qualquer despejo forçado, especialmente os que envolvam grandes grupos de pessoas, o Estado deve explorar "todas as alternativas possíveis", consultando as pessoas afetadas, a fim de evitar ou de minimizar o uso da força ou, ainda, de impedir o despejo. " (SAULE JUNIOR \& MENEZES, 2005, p. 142)

Particularmente, se trouxermos tal questão para uma discussão da cidade de Araguaína, pode-se afirmar com clareza que é bastante expressivo o número de ocupações em propriedades urbanas, sejam públicas ou privadas, em uma cidade do porte de Araguaína, considerada uma cidade média ${ }^{2}$. É também significativo a velocidade com que este problema vem se instalando no espaço urbano da cidade. Apenas a título de exemplo, temos alguns setores, como: Monte Sinai, Maracanã, Alto Bonito, Tiúba, Cimba, Xixebal, dentre outros.

É possível que as origens desse problema estejam relacionadas à própria montagem da estrutura fundiária urbana da cidade, a qual vem se projetando desde os primeiros momentos de expansão constatados nas décadas de 1960, 1970 e 1980 do século passado. Na maioria dos casos, as pessoas vinham para Araguaína, se instalavam, e ocupavam áreas dentro da cidade de maneira aleatória, sem qualquer documentação que garantisse essa ocupação.

\footnotetext{
${ }^{2}$ Apesar das dificuldades e da complexidade que envolve o termo e o tema cidade média considera-se que sua "particularidade reside no pressuposto de uma específica combinação entre o tamanho demográfico, funções urbanas e organização de seu espaço intra-urbano, por meio da qual pode-se conceitualizar a pequena, média e a grande cidade, assim como a metrópole. " (CORRÊA, 2007, p. 23)
} 
Dessa forma, as pessoas ganhavam o direito de morar, construindo suas casas, aquelas com menor poder aquisitivo construíam com tábua, pois a madeira era abundante para a época descrita acima, outras com maior poder aquisitivo se apropriavam de áreas maiores e muito posteriormente, quando perceberam o processo de expansão urbana da cidade, criavam os loteamentos, e comercializavam a terra, já valorizadas sobre o signo do urbano.

Na cidade de Araguaína pode-se afirmar que a problemática da moradia, repousa, dentre outras, a questões que julgamos hipoteticamente mais relevantes, quais sejam: o alto preço cobrado pelo mercado imobiliário local seja, residências ou terrenos, a falta de competitividade do mercado de imóveis local e também as deficitárias políticas públicas habitacionais, voltadas essencialmente para os grupos sociais de baixa renda. Daí, porque, assiste-se constantemente, a esse processo de ocupação de áreas públicas e privadas.

Geralmente a valorização e os lucros obtidos pela venda da terra urbana ocorrem através do processo de especulação imobiliária. Essa situação leva-nos a pensar que a existência do latifúndio urbano merece ser mais amplamente discutido, pois esta situação tem originado uma série de problemas na cidade.

No momento contemporâneo, o que se tem observado é que muito mais do que cumprir uma função social, a terra urbana tem cumprido as regras do mercado. Daí, porque tem-se assistido, constantemente, a intensificação dos problemas urbanos em várias cidades do país. Araguaína, portanto, não tem fugido a essa regra.

Com diferença de grau e de intensidade, todas as cidades brasileiras exibem problemáticas parecidas. O seu tamanho, tipo de atividade, região em que se inserem etc. são elementos de diferenciação, mas em todas elas problemas como os do emprego, da habitação, dos transportes, do lazer, da água, dos esgotos, da educação e saúde, são genéricos e revelam enormes carências. (SANTOS, 1993, p. 95)

Sendo assim, tal fato se reproduz nos dias atuais quando se percebe que um percentual significativo das pessoas que moram na cidade de Araguaína não detém a escritura ou título de posse da terra em que ocupam, pois não receberam, porque também, muitas vezes não compraram a terra em que moram e quando compram não regularizam a situação fundiária junto aos órgãos competentes. O Setor "Monte Sinai" é um, dos muitos exemplos, que temos presenciado na cidade.

Se trouxermos essa discussão para a escala do território brasileiro, pode-se observar diversas particularidades, que variam e torna mais complexa a análise do problema habitacional no Brasil. Ou seja, cada região, cada estado, vão apresentar características distintas que ora se 
assemelham, ora apresentam realidades bem diferentes. Daí mais uma vez a necessidade do estudo e compreensão do problema habitacional em um nível mais específico, sem generalizações, mais com informações precisas, na perspectiva de diligenciar políticas públicas vinculadas à questão habitacional local, no caso em estudo, para Araguaína.

Além disso, emerge a necessidade de se discutir e refletir em conjunto a problemática da moradia e da cidade. Se queremos uma moradia com qualidade, segundo regulamenta a ONU, temos que ter um espaço adequado para a instalação dessa moradia. Não há como instalar os pobres em áreas de riscos, propagandeando que se está a fazer política habitacional com uma preocupação social. Isto não confere legitimidade social a tais políticas. Um espaço urbano saudável é condição ímpar para uma moradia adequada. É por essa diretriz que discutiremos na secção seguinte o direito à moradia adequada no âmbito da cidade de Araguaína mostrando o distanciamento entre o discurso e a prática das políticas públicas de moradia social.

\section{O direito à moradia em Araguaína: confrontando discursos e práticas}

O registro da construção das primeiras residências como sendo fruto de política habitacional, vem da década de 1970, mais precisamente em 1977, quando não existia estado de Tocantins, sendo Araguaína pertencente ao então estado de Goiás. A Vila Couto Magalhães foi construída como parte integrante do programa governamental de moradia popular do governo goiano, que por sua vez estava integrado aos programas desenvolvidos pelo Banco Nacional de Habitação - BNH que fazia parte do Sistema Financeiro de Habitação - SFH, do governo federal. Entretanto, os diálogos informais mantidos com alguns moradores de outro setor da cidade, denominado "Vila Aliança" revelaram que esta Vila também foi construída na década de 1970. Como não se tem registros oficiais nos órgãos municipais ou federais resolvemos considerar a Vila Couto Magalhães e a Vila Aliança como os primeiros empreendimentos de políticas públicas de moradia social construídos em Araguaína.

A Vila Couto Magalhães foi anunciada, por assim dizer, pela Companhia de Habitação de Goiás - COHAB-GO no dia 21 de julho de 1977. A área total onde seriam implantadas as moradias é de $145.200 \mathrm{~m}^{2}$. A construção da referida Vila Couto Magalhães teve início em 1980, entretanto, em 1983 a mesma foi invadida por taxistas. O regime de construção se deu em ritmo de mutirão na época do governo Iris Rezende, que governou Goiás pela primeira vez de 1983-1986. Nesse período em função da guerra das Malvinas, a Vila passou a se chamar "Vila Malvinas", mas teve seu nome original retomado após o término do conflito que envolveu Inglaterra e Argentina. 
Outro exemplo de política pública habitacional em Araguaína é a construção do Conjunto Residencial Patrocínio, ocorrido no começo da década de 1990, precisamente em 1994. Construído com uma infraestrutura básica composta por energia elétrica e fornecimento de água potável, mas sem asfaltamento das ruas e com poucas áreas de lazer para seus moradores. Este conjunto residencial abriga mais de 400 unidades habitacionais.

Para uma melhor visualização da política de moradia social de Araguaína, construiu-se o quadro 1 , onde é evidenciado o déficit habitacional. Já no quadro 2, reporta-se a um levantamento dos setores que possuem estas políticas públicas. A construção desses dados só foi possível após o levantamento realizado a campo, onde percorremos todos os setores da cidade para constatarmos a existência das políticas públicas de moradia social.

Quadro 1: Brasil, Região Norte, Tocantins, Araguaína: Déficit Habitacional - 2008

\begin{tabular}{|c|c|c|}
\hline \multirow{2}{*}{ Especificação } & Déficit habitacional em valores absolutos \\
\cline { 2 - 3 } & Total & Urbano \\
\hline Brasil & 5.546 .310 & 4.629 .832 \\
\hline Região Norte & 555.130 & 448.072 \\
\hline Tocantins & 59.681 & 36.766 \\
\hline Araguaína $^{3}$ & 4.991 & - \\
\hline
\end{tabular}

Fonte: Fundação João Pinheiro, IBGE, 2008. Organizado por: Vasconcelos Filho- 2012

\footnotetext{
${ }^{3}$ Este valor corresponde aos dados fornecidos pela Fundação João Pinheiro/PNUD, para o ano 2000. Nos levantamentos mais recentes que correspondem a 2008, a referida Fundação não calculou este valor por município. Outro dado relevante é que para o Movimento Nacional de Luta pela Moradia - MNLM de Araguaína, para o ano de 2008, este número equivale a um déficit de 16.000 moradias.
} 
Quadro 2: Araguaína: Setores que abrigam políticas públicas de Moradia Social

\begin{tabular}{|c|c|c|c|}
\hline $\begin{array}{c}\text { Denominação das áreas que } \\
\text { abrigam moradia social }\end{array}$ & $\begin{array}{c}\text { Quantidade de } \\
\text { habitações }\end{array}$ & $\begin{array}{c}\text { Dimensão da } \\
\text { moradia em m² }\end{array}$ & $\begin{array}{c}\text { Período de } \\
\text { construção }\end{array}$ \\
\hline Vila Couto Magalhães & 301 & 33,50 & $1982-1984$ \\
\hline Conjunto Residencial Patrocínio & 400 & 46,97 & 1994 \\
\hline Vila Aliança & 172 & 42,00 & 1970 \\
\hline Vila Azul & 950 & 40,37 & $2010-2011$ \\
\hline Vila Ribeiro & 150 & 77,00 & 1992 \\
\hline *Céu Azul & - & 32,00 & 1994 \\
\hline Costa Esmeralda I e I & 847 & 40,29 & $2012-2013$ \\
\hline Jardins Mônaco & 117 & 32,00 & $2011-2012$ \\
\hline Jardim das Flores & 256 & 31,90 & $2002-2005$ \\
\hline Setor Morada do Sol & 200 & 23,74 & 2005 \\
\hline *Setor Ana Maria & - & 23,74 & 2005 \\
\hline Santa Mônica & 42 & 27,88 & 2002 \\
\hline Setor Universitário & 123 & 30,09 & 2006 \\
\hline *Loteamento Jardim Boa Vista & 416 & - & $2012-2013$ \\
\hline
\end{tabular}

Fonte: Pesquisa realizada a partir da observação das políticas públicas em vários setores da cidade de Araguaína. Organizada por Vasconcelos Filho, João Manoel de. Em junho/2012.

*Algumas informações para estas áreas não existem em nenhum órgão oficial pesquisado, a exemplo da Caixa Econômica Federal, Secretaria de Habitação do Tocantins e Prefeitura de Araguaína. A dimensão das moradias foi coletada a partir da documentação fornecida pelos proprietários dos imóveis.

A visita aos vários setores da cidade que abrigam políticas moradias social possibilitou a construção do quadro 2 onde a partir dessas informações tem-se a compreensão da dimensão de tais políticas na cidade de Araguaína. Em alguns setores, a exemplo do Ana Maria, Santa Mônica, Morada do Sol, Araguaína Sul, Vila Ribeiro, Setor Universitário, Céu Azul e Vila Couto Magalhães, também se registram construções de moradias que não foram frutos das políticas públicas firmadas entre o governo federal e a Prefeitura, ou mesmo apenas construídas pelos investimentos federais.

Assim, o que se encontrou em cada um desses setores, é que apenas parte dele foi destinada a produção desses imóveis. O mesmo vai acontecer também com o Jardim Mônaco, um loteamento em que parte dele será utilizada para a construção de 117 casas para os grupos sociais de baixa renda.

Conforme já foi apontado o objetivo desta etapa da pesquisa ocorre por uma dupla necessidade. Num primeiro momento teve-se que percorrer muitos bairros da cidade em função de não obtermos informações precisas por parte da Prefeitura Municipal de Araguaína, onde estariam localizados os programas habitacionais construídos em parcerias com outras instâncias governamentais. Após esta etapa buscamos informações também na Caixa Econômica Federal e a 
Secretaria de Habitação da Prefeitura. As informações a esse respeito só eram dos programas mais recentes, ou seja, aqueles construídos a partir do ano 2000.

Esse estudo possibilitou a catalogação de 14 setores que abrigam as políticas públicas de moradia social, segundo aponta o quadro 2. Em um segundo momento, a necessidade de percorrer tais áreas objetivou investigar a partir dos parâmetros estabelecidos pela ONU, bem como o que rege os princípios da cidade saudável e da Carta Mundial do Direito à cidade, se estas moradias estariam em conformidade com o que estabelece esses organismos internacionais e os referidos documentos. Nos 14 setores visitados, foram feitos registros fotográficos tanto das moradias quanto da infraestrutura física dos bairros. Após isto é que se confirmou que o único bairro que se aproximava dessa perspectiva seria o conjunto residencial Jardim das Flores, em face do que foi detidamente observado, mas vale salientar que o mesmo está muito distante da prerrogativa da ONU no que diz respeito a existência de uma moradia adequada.

\section{Residencial Jardim Flores: Análises sob a perspectiva do direito à moradia adequada}

O levantamento empírico relatado na secção anterior estabeleceu uma base que nos deu respaldo para a escolher o Conjunto Residencial Jardim das Flores como o cenário de aplicação dos formulários de pesquisa, para posteriormente analisar se este conjunto cumpre, a contento, as exigências estabelecidas pela ONU no que tange a moradia adequada onde os Direitos humanos, econômicos, sociais e culturais são respeitados.

A história da construção do Conjunto Residencial Jardim das Flores tem início em 2001, quando várias famílias instaladas as margens da Rodovia Estadual TO-222, precisamente no canteiro central desta rodovia, viviam em um espaço precário sujeitas á toda sorte de riscos, desde a questão da violência, acidentes de trânsito, bem como a questão da saúde, uma vez que estas conviviam com o lixo e com a poluição do córrego "Baixa Funda" situado nas proximidades desse aglomerado subnormal. Assim, neste mesmo período foi firmado o projeto entre o Ministério das Cidades/Caixa Econômica Federal/BID/Programa Habitar Brasil/Prefeitura Municipal de Araguaína.

A Prefeitura Municipal, através da sua gestora, prometeu que as famílias iam desocupar esta área e no local seria construído um grande parque para usufruto da cidade com um todo. As famílias foram retiradas e transferidas para o conjunto Residencial Jardim das Flores. Entretanto, a implantação do parque na área que fora prometida, nunca saiu do papel. Hoje, 7 anos após a construção da última etapa do residencial para onde foram alocadas as famílias, a prefeitura 
Municipal de Araguaína, entregou a área que seria construído um parque ambiental a iniciativa privada, concedeu a venda de lotes para a instalação de equipamento comerciais.

Aqui, mais uma vez, é possível falar sobre o triunfo do mercado sobre os direitos do cidadão. Área pública, como o próprio nome diz, é comum a todos, cabendo ao direito e usufruto da sociedade como um todo. Não cabendo ao Estado, seja em qualquer escala de atuação, negociar tais áreas em benefício próprio. É assim também que se nega a cidade, que se nega também a possibilidade, ainda mais numa cidade como Araguaína, carente de espaços de lazer, para o cidadão utilizar esses espaços em momento lúdicos.

Retornando a fundação do Jardim das Flores, a partir de 2002 teve início a construção das primeiras moradias. O projeto previa a construção de 256 moradias. A primeira fase foi entregue em 2004, com o total de 175 moradias. Já a segunda etapa foi entregue em 2005, com 81 moradias. As casas são construídas em alvenaria, contendo 2 quartos, sala/cozinha conjugadas, 1 banheiro e uma lavanderia fora da moradia. A área total do imóvel é de 31,94m².

Objetivando investigar e refletir detidamente sob o aspecto do direito à moradia adequada segundo a resolução da ONU, realizamos uma pesquisa qualitativa com o uso de formulários que elucidava aspectos relevantes quanto a qualidade de vida, o direito à moradia, o direito à cidade, a percepção do que se entende por uma moradia e uma cidade saudável, bem como o que os seus moradores compreendem a respeito de uma cidade democrática. Outras questões relevantes foram apresentadas para se chegar a compreensão do direito à moradia adequada.

Esta metodologia utilizada foi relevante pois além das questões postas no formulário, os diálogos informais foram enriquecedores para a compreensão mais sistematizada desta investigação. Sabendo que o referido residencial abriga um total de 256 moradias, decidiu-se por aplicar uma soma maior de amostragem daquela estabelecida pelo IBGE, que é de 10\% do total do universo pesquisado. Esta escolha se deu em face de abranger o maior número possível de famílias entrevistadas.

Entretanto, o que definiu o número de formulários não foi apenas o aspecto quantitativo do mesmo, mas em primeira instância as respostas que eram dadas pelos entrevistados. Observando o conteúdo do que fora respondido, resolveu-se por trabalhar nas duas etapas construídas no residencial, de modo que 50 famílias foram contempladas pela pesquisa. Totalizando $19,53 \%$ das famílias.

O formulário de pesquisa encontra-se distribuídos em três seções. A primeira, está relacionada com a família. Nela, perguntou-se sobre o sexo do chefe da família, sua faixa etária, 
grau de instrução escolar, estado civil, rendimento familiar, a cidade de origem, fatores que condicionaram sua vinda para Araguaína e como imaginavam a cidade.

A segunda seção do formulário, remete-se a questões relativas a moradia, na perspectiva do direito a este bem. Aqui a preocupação é claramente voltada para as condições da moradia, do espaço de convivência familiar. Discute-se desde os caminhos que foram traçados para ter o direito à moradia, ou seja, para adquiri-la, até suas relações com espaço de habitar.

É relevante investigar neste intuito como a família adquiriu a casa, de que forma ela vê a participação do poder público em suas diversas escalas para a promoção da moradia social. Verificou-se ainda se esta família paga alguma quantia por esta moradia, se a casa atende suas necessidades, se ela pretende reformar ou vender a casa. Buscou-se observar se gostariam de mudar de bairro e porquê. Indagou-se por fim, o que o morador considera uma casa saudável e o que ela representa em vossas vidas.

É importante destacar que os diálogos mantidos com os entrevistados ultrapassam os questionamentos postos nos formulários. Em vários momentos histórias de vidas traçadas no espaço-tempo vieram à tona, extrapolando o que estava previsto no referido formulário. As condições de vida das famílias, dentre outras subjetividades vieram à baila no presente trabalho.

Finalmente a terceira e última seção refere-se ao bairro e à cidade, na perspectiva qualitativa dos serviços oferecidos e da estrutura do bairro, que também está presente nos equipamentos urbanos de uso coletivo. Preocupou-se também em captar a percepção que o morador deste bairro tem em relação à cidade.

A seção três levanta informações sobre a estrutura física do Jardim das Flores, incluindo os equipamentos urbanos de uso coletivo que se fazem presentes, a qualidade dos serviços de transporte público, de educação e saúde, a qualidade ambiental, representada pelos parques e praças, que também se remetem a espaços de lazer como o campo de futebol e a frequência da coleta de lixo. A última parte desta seção está mais voltada para as representações urbanas, ou seja, procurou-se assimilar o que as famílias entendem por direito à cidade, o que eles sabem dizer sobre uma cidade saudável e democrática, quais os caminhos que levaram a efetivação destes modelos de cidades e se elas consideram Araguaína uma cidade democrática e saudável.

A análise inicial separou por gênero as respostas que foram obtidas nas respectivas entrevistas, pois achou-se relevante entender inicialmente como se comporta aqui o conjunto das famílias que são chefiadas pelos homens e aquelas que têm as mulheres em seus comandos. Daí as questões postas inicialmente, que são relativas as famílias, possibilita fazer este tipo de análise. 
Para uma melhor visualização dos resultados obtidos sistematizou-se os dados em três partes, de acordo com as temáticas estabelecidas no formulário. Assim o quadro (5) trata das questões relativas à família, o quadro (6) evidencia questões da moradia e os quadros (7) e (7a) salientam as percepções do lugar da moradia e da cidade.

Quadro 5: Araguaína/Jardim das Flores - Composição da família - 2012

\begin{tabular}{|c|c|c|c|c|c|}
\hline \multirow{2}{*}{\multicolumn{2}{|c|}{$\begin{array}{l}\text { Dados sobre a familia } \\
\text { Chefes de família }\end{array}$}} & \multicolumn{2}{|c|}{ \% Masculino } & \multicolumn{2}{|c|}{$\%$ Feminino } \\
\hline & & \multicolumn{2}{|c|}{$72 \%$} & \multicolumn{2}{|c|}{$28 \%$} \\
\hline \multirow{2}{*}{$\begin{array}{l}\text { Faixa etária } \\
\text { predominante }\end{array}$} & $30-50$ anos & \multicolumn{2}{|c|}{$55 \%$} & \multirow{2}{*}{\multicolumn{2}{|c|}{$92,85 \%$}} \\
\hline & $30-60$ anos & & & & \\
\hline \multicolumn{2}{|c|}{ Grau de instrução } & \multirow{2}{*}{\multicolumn{2}{|c|}{$16,66 \%$}} & \multirow{2}{*}{\multicolumn{2}{|c|}{$35,71 \%$}} \\
\hline \multicolumn{2}{|c|}{1 a fase do E.F. 1 o ao 50 ano } & & & & \\
\hline \multicolumn{2}{|c|}{ 2a fase do E.F. 6o ao 9o ano } & \multicolumn{2}{|c|}{$13,88 \%$} & \multicolumn{2}{|c|}{$7,14 \%$} \\
\hline \multicolumn{2}{|c|}{ Ensino Médio completo } & \multicolumn{2}{|c|}{$36,11 \%$} & \multicolumn{2}{|c|}{$50 \%$} \\
\hline \multicolumn{2}{|c|}{ Ensino Médio incompleto } & \multicolumn{2}{|c|}{$11,11 \%$} & \multicolumn{2}{|c|}{$0 \%$} \\
\hline \multicolumn{2}{|c|}{ Ensino Superior } & \multicolumn{2}{|c|}{$11,11 \%$} & \multicolumn{2}{|c|}{$0 \%$} \\
\hline Analf & & \multicolumn{2}{|c|}{$11,11 \%$} & \multicolumn{2}{|c|}{$7,14 \%$} \\
\hline \multicolumn{2}{|c|}{ Estado civil } & $\begin{array}{l}\text { Casados } \\
88,88 \%\end{array}$ & $\begin{array}{c}\text { Solteiros } \\
0 \%\end{array}$ & $\begin{array}{c}\text { Casadas } \\
0 \%\end{array}$ & $\begin{array}{l}\text { Solteiras } \\
78,57 \%\end{array}$ \\
\hline \multirow{2}{*}{\multicolumn{2}{|c|}{ Rendimento familiar }} & $1-3 \mathrm{SM}$ & $5-10$ SM & \multicolumn{2}{|c|}{ 1-3 SM } \\
\hline & & $80,56 \%$ & $19,44 \%$ & \multicolumn{2}{|c|}{$100 \%$} \\
\hline \multirow{2}{*}{\multicolumn{2}{|c|}{ Quanto a origem da família* }} & \multicolumn{2}{|c|}{ Natural de Araguaína } & \multicolumn{2}{|c|}{ Imigrantes } \\
\hline & & \multicolumn{2}{|c|}{$20 \%$} & \multicolumn{2}{|c|}{$80 \%$} \\
\hline \multicolumn{2}{|c|}{ Fatores que condicionaram a migração } & \multicolumn{2}{|c|}{$\begin{array}{l}\text { Econômicos } \\
70 \%\end{array}$} & \multicolumn{2}{|c|}{$\begin{array}{c}\text { Estudos e saúde } \\
30 \%\end{array}$} \\
\hline
\end{tabular}

Fonte: Pesquisa empírica realizada por VASCONCELOS FILHO, nos meses de junho, julho e agosto de 2012, no Conjunto Residencial Jardim das Flores, Araguaína-TO.

* No que diz respeito a origem das famílias e os fatores que motivaram a migração não foi considerada a diferença entre os gêneros.

Para se ter uma visão geral desta questão, dos 50 formulários aplicados 36 famílias tem os homens como chefe e 14 famílias são chefiadas pelas mulheres. Em dados relativos isto quer dizer que $72 \%$ dos domicílios pesquisados são representados por homens contra $28 \%$ em que as mulheres estão em seus comandos. Quanto a faixa etária do público masculino, constatou-se que 4 estão entre 18-25 anos, 11 estão entre 40-50 anos, 9 estão entre 30-40 anos, 6 encontra-se na faixa etária de 50-60 anos e apenas 6 homens são idosos, onde 3 estão situados entre 60-70 anos e 3 possuem mais 70 anos. 
Assim as faixas etárias predominantes destes chefes de famílias são aquelas respectivamente entre 40-50 anos e 30-40 anos. Juntas elas perfazem 55,55\% dos domicílios em que os homens são os responsáveis pela família. Ou seja, em mais da metade destas famílias os homens estão entre 30-50 anos. Inferindo-se que este público é relativamente novo, assumiram responsabilidades familiares ainda muito cedo.

Já para os domicílios representados pelas mulheres. Em 4 moradias elas estão entre 30-40 anos, em 5 lares elas estão entre 40-50 anos, em 4 elas se situam na faixa de 50-60 anos e em 1 moradia ela se encontra entre 60-70 anos. Como se vê a distribuição de faixa etária entre as mulheres é mais equitativa, diferenciando-se apenas de 1 que possuem mais de 60 anos de idade. Mas em relação aos homens os dados se repetem quando considera-se que elas estão entre 40-50 anos de idade. Já para o total do universo pesquisado no público feminino isto vai mudar pois $92,85 \%$ delas possuem de $30-60$ anos de idade. Nesse contexto estas mulheres que chefiam suas moradias são 10 anos mais velhas em relação ao limite de idade dos chefes masculinos.

O grau de escolaridade variou bastante no público masculino. Sendo assim, em 13 domicílios os homens possuem o ensino médio completo. Em 4 moradias eles possuem ensino médio incompleto. Em 5 eles estudaram apenas a 2a fase do ensino fundamental. Em 6 residências eles cursaram até a primeira fase do ensino fundamental. E em apenas 4 lares, os chefes de família possuem o curso superior e a mesma quantidade é de analfabetos.

Aqui se chama a atenção para três pontos principais. O primeiro seria para dizer que apenas $36,11 \%$ destes homens cursaram o ensino médio. Índice considerado muito baixo. Mas isto se torna ainda mais deficitário no sentido dos anos que estas pessoas estudaram, do grau de qualificação delas, quando se constatou que apenas $11,11 \%$ possuem curso superior. 0 terceiro destaque é dado para estes mesmos percentuais de chefes de famílias que se declararam analfabetos.

O perfil do público feminino vai diferenciar-se do masculino. Enquanto $36,11 \%$ dos homens cursaram o ensino médio completo. Esta média sobe para 50\% das famílias que são conduzidas por mulheres. Entretanto, é preciso chamar a atenção que nenhumas delas possuem curso superior e apenas 1 mulher se declarou analfabeta.

Quanto ao estado civil, é digno de nota registrar que 88,88\% dos homens são casados. Enquanto as matriarcas das famílias entrevistadas $78,57 \%$ são solteiras. Grande parte destas mulheres foi abandonada pelos seus parceiros e apenas 1 se declarou viúva. Elas assumiram sozinhas as responsabilidades de conduzir seus lares e filhos. Regra geral, as histórias de vida foram 
relatadas por este público, desta sua trajetória do lugar de origem, passando pela moradia precária as margens da rodovia estadual TO-222, até conseguirem a casa no Jardim das Flores.

Tratando-se do orçamento familiar em $100 \%$ das famílias matriarcais, constatou-se que seus rendimentos estão entre 1-3 salários mínimos. Ou seja, estão naquela faixa de renda onde se encontra mais de $80 \%$ do déficit habitacional brasileiro. Isto também se repete nos domicílios chefiados pelos homens. Pois em 80,56\% destas famílias o rendimento é de 1-3 salários mínimos e apenas $19,44 \%$ dos homens declaram receber entre 5-10 salários mínimos. De fato, isto faz crer que o residencial em sua maioria abriga famílias de baixa renda. Pessoas, que se encontram excluídas do circuito produtivo, ou que se insere nele, de forma marginalizada, conforme atesta Martins (1997), quando afirma que não existe exclusão, mas antes uma inclusão marginalizada, debilitada no processo produtivo.

Esta análise vai tomando novo direcionamento a partir do perfil diferenciado das questões que são tratadas. Neste momento, deixa de ser relevante separar essa questão de gênero indo, portanto, para o cômputo geral das famílias contempladas por esta investigação. Isto também é justificado pelo fato das famílias, independente do gênero ser de imigrantes. Vieram assim, de outras cidades do estado do Tocantins, em sua maioria.

Do total de entrevistados, ou seja, como já foi dito de 50 famílias, 40 são de outros núcleos urbanos. Destas, apenas 8 vieram de cidades que pertencem ao Tocantins e 32 famílias vieram de outras regiões do país, como o Nordeste, Sudeste e Sul do Brasil, principalmente. Da região Nordeste, observou-se que grande parte destas famílias é oriunda dos estados do Maranhão e Piauí. Isto referenda o testemunho histórico da fundação de Araguaína, desde seus primórdios enquanto povoado, uma vez que esta cidade foi fundada por piauienses na segunda metade do século XIX.

Constatou-se assim que $80 \%$ destes moradores são de imigrantes. Isto também reforça a tese de que esta cidade se encontra em uma área de expansão da fronteira agrícola brasileira, notadamente, da região Norte do território brasileiro. Cidade esta que ainda nos dias atuais recebe um significativo contingente de pessoas, não mais para ocupar postos de trabalho no campo, mas principalmente para fixar residência na cidade, e assim desenvolver atividades tipicamente urbanas.

Aponta ainda para uma forte e recente configuração da migração inter-regional. Se nas décadas de 1970, 1980 e começo dos anos de 1990, ainda era muito significativa a migração das regiões Norte-Nordeste para o Sudeste brasileiro. Agora é bastante expressiva, a migração que 
vem do Sudeste-Sul do Brasil, para a Amazônia Legal como um todo, da qual o estado do Tocantins faz parte. Embora, é preciso relembrar que desde a implantação dos eixos rodoviários que fizeram e faz o processo de integração nacional continuar, que se assiste à chegada destes novos moradores a cidade de Araguaína. Mas agora é um novo momento, e os motivos também são outros.

É impressionante o grau de satisfação destes moradores com a cidade. Dos entrevistados, 40 famílias responderam que gostam de Araguaína, não pretendem, portanto, voltar aos seus lugares de origem. Representando 80\% do total. Das 10 famílias que demonstraram interesse de voltar aos seus lugares de origem, uma nos chamou particular atenção. Trata-se de uma senhora de 70 anos de idade que residia no município de Babaçulândia-TO, a 60 km de distância de Araguaína.

Esta senhora foi uma das muitas famílias que tiveram suas propriedades, suas moradias tomadas pela água resultante da construção da Hidrelétrica do Estreito, situada no município de Estreito-MA, a cerca de $180 \mathrm{~km}$ de Babaçulândia. Após a construção da barragem e com a formação do lago, cerca de $30 \%$ da área urbana deste município, segundo dados da prefeitura, desapareceu por completo e com ela muitas histórias de vida. Uma delas é desta senhora, que morava a mais de 50 anos neste local e que viu desaparecer por completo, não apenas sua moradia e propriedade em si, mas um quadro de referência de vida que ficou debaixo da água do lago que se formou com a construção da hidrelétrica.

No relato foi dito que a indenização recebida não supriu suas necessidades, segundo a mesma senhora "o dinheiro só deu para comprar esta casa". Relatou que não sabe morar na cidade, tudo o que sabia fazer está relativo as atividades desenvolvidas no campo. Por isto chora todos os dias, pois sempre tinha uma pequena criação de animais e plantava em um roçado alguns produtos de subsistência, agora não sabe o que vai fazer.

Os motivos que condicionaram a vinda destas famílias para Araguaína, também foram investigados. Mais da metade, ou seja, 28 famílias vieram em busca de melhores condições de vida, encontrar um trabalho que pudessem Ihes dar sustentação. Assim, os condicionantes econômicos foram responsáveis pela migração de 70\% destas famílias. Em 11 famílias foram constatadas que os motivos da migração estavam relacionados a busca por melhores condições de saúde e educação, principalmente dos filhos.

Quanto as expectativas em relação a Araguaína as respostas variaram bastante, pois 14 famílias acreditavam que esta era uma cidade grande, desenvolvida. Mas 18 famílias não faziam 
ideia do que iriam encontrar na cidade, como esta seria, a sua estrutura e como seriam recebidas pela sociedade local. Destas, 5 acharam a cidade pequena e ruim e 3 não souberam responder.

Quanto a tipologia da moradia pode-se atestar que todas são construídas em alvenaria e possuem um só padrão arquitetônico com as mesmas dimensões, ou seja, 31,9m², composta por 2 quartos, 1 sala que também serve de cozinha, 1 banheiro e uma lavanderia que fica fora da moradia. As figuras 5 e 6 ilustram a realidade desse residencial.

Figura 5: Conjunto Residencial Jardim das Flores.

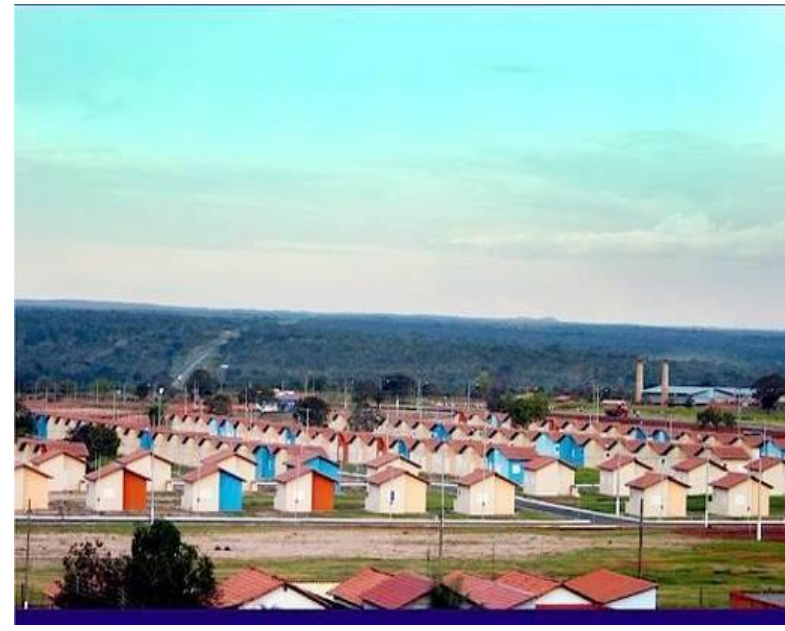

Fonte: Silva, 2005

Figura 6: Modelo de moradia social do Residencial Jardim das Flores

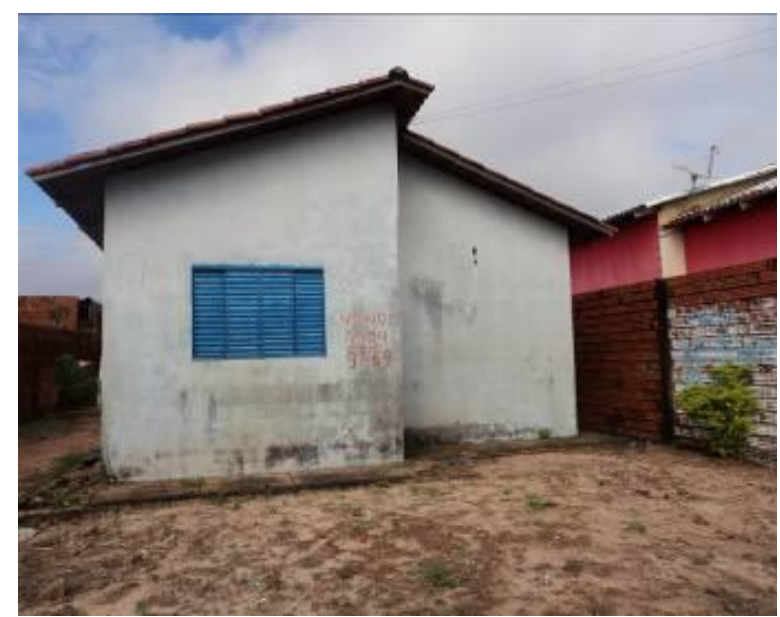

Fonte: Vasconcelos Filho/2013 
Partindo deste momento é que o formulário suscita as percepções do direito à moradia, quando indaga sobre os caminhos que foram trilhados para a conquista deste bem. Assim o quadro 6 vai tratar especificamente do direito à moradia e como esses moradores tiveram que trilhar os caminhos para conquistar esse direito.

Aqui também os relatos foram muitos e extrapolaram o que previa os formulários. As histórias de vida também vieram à tona. Em vários momentos, principalmente quanto aos chefes de famílias femininos, me foi questionado. "Ora, se a casa é uma condição para a vida, porque é tão difícil conseguir uma moradia?"

Em outras palavras elas quiseram externar que esse é um direito natural de qualquer indivíduo, ou seja, o de morar, mas morar com qualidade. Neste momento, as entrevistas, tanto para as famílias, quanto para o pesquisador foram acompanhadas de uma forte carga emocional. Embora a ciência exija um certo distanciamento deste aspecto e um comportamento mais racional, de não envolvimento, é praticamente impossível não se emocionar com as histórias que devem ser pacientemente ouvidas. Foi neste momento que a moradora da Avenida dos Flamboyants, falava na altura da entrevista sobre as condições que vivia com a filha no canteiro central da rodovia TO222.

Era muito difícil nossas condições. A moradia era de tábua, coberta com uma Iona plástica. Quando chovia pingava muito, além disto a água invadia a casa e alagava tudo. Passei noites inteiras puxando água dentro de casa. As tábuas eram tão separadas uma da outra que eu tinha que colocar papelão para tapar os buracos afim das pessoas não me verem dentro de casa quando passavam na rua. (Relato de uma moradora do Residencial Jardim das Flores, 2012)

A maioria das famílias moradoras deste residencial veio do canteiro central que margeia a rodovia estadual TO-222, também denominada via Filadélfia, como já foi exposto anteriormente. Muitas destas famílias, antes de ir para este canteiro moravam em outras partes da cidade, notadamente, na periferia pobre que estão nas cercanias do contato entre a parte urbana e a mata do Cerrado, já bastante degradada. A possibilidade de comprar um lote junto a esta rodovia davaIhe uma melhor condição de acessibilidade, de localização junto a escolas, postos de saúde e comércio, pois se encontra muito próximo à Área Central da cidade de Araguaína. No quadro 6 evidencia-se com mais clareza a problemática relativa à moradia. 
Quadro 6: Araguaína/Jardim das Flores: Questões relativas ao direito à moradia

\begin{tabular}{|c|c|}
\hline \multicolumn{2}{|r|}{ A busca pela moradia e suas representações } \\
\hline $\begin{array}{l}\text { Quais os caminhos } \\
\text { percorridos para } \\
\text { adquirir a casa própria }\end{array}$ & $\begin{array}{l}\text { 78\% das famílias entrevistadas adquiriram a casa pelo Programa Habitar } \\
\text { Brasil. Apenas } 18 \% \text { compraram seus imóveis de outros proprietários. Já } \\
4 \% \text { das famílias vivem de aluguel. }\end{array}$ \\
\hline $\begin{array}{l}\text { De que forma analisa a } \\
\text { participação do Estado } \\
\text { na promoção da } \\
\text { moradia }\end{array}$ & $\begin{array}{l}\text { 100\% dos entrevistados avaliaram como boa a participação do Estado } \\
\text { na política de moradia social. Apenas comentaram que ainda há uma } \\
\text { necessidade de se construir mais moradias. }\end{array}$ \\
\hline $\begin{array}{l}\text { Quanto a fa } \\
\text { por } n\end{array}$ & $\begin{array}{c}\text { Das } 50 \text { famílias entrevistas, } 48 \text { são proprietárias do imóvel, assim pela } \\
\text { política do Programa Habitar Brasil, estas casas foram doadas, não } \\
\text { necessitam, portanto, de pagamento de quaisquer quantias. Apenas } 2 \\
\text { famílias moram de aluguel. }\end{array}$ \\
\hline $\begin{array}{l}\text { A casa } \\
\text { necess } \\
\text { far }\end{array}$ & $\begin{array}{l}\text { Nenhuma família entrevis } \\
\text { necessidades. Cerca de } \\
\text { reformado a }\end{array}$ \\
\hline $\begin{array}{l}\text { Pretendem reformar a } \\
\text { casa? }\end{array}$ & $\begin{array}{l}\text { Apenas } 10 \% \text { responderam que não gostariam de reformar, pois } \\
\text { consideravam de bom tamanho e de boa qualidade a estrutura } \\
\text { residencial. }\end{array}$ \\
\hline $\begin{array}{l}\text { Em sua opinião o que } \\
\text { seria uma casa } \\
\text { saudável? }\end{array}$ & $\begin{array}{c}\text { As respostas dos moradores demonstram que a casa para ser saudável } \\
\text { é preciso que o ambiente de entorno também seja saudável. Assim } \\
\text { apontaram além do conforto da moradia, esta precisa ter um jardim, } \\
\text { limpeza e espaços amplos. Já o local como um todo deve ter segurança } \\
\text { e ser arborizado. }\end{array}$ \\
\hline $\begin{array}{l}\text { O que a casa representa } \\
\text { em sua vida? }\end{array}$ & $\begin{array}{c}\text { Indiscutivelmente, em resumo todas as famílias responderam que se } \\
\text { trata do maior bem de vossas vidas. }\end{array}$ \\
\hline
\end{tabular}

Fonte: Pesquisa empírica realizada por VASCONCELOS FILHO, nos meses de junho, julho e agosto de 2012, no Conjunto Residencial Jardim das Flores, Araguaína-TO.

Das 50 famílias entrevistadas, 39 adquiriram suas moradias pelo Programa Habitar Brasil, estabelecido com a Prefeitura Municipal de Araguaína, representando 78\% dos moradores contemplados pela pesquisa. Apenas 9 famílias compraram suas moradias de outros proprietários e apenas 2 moram de aluguel. Para todos os entrevistados a participação do Estado foi avaliada como boa, mas salientaram que ainda não é suficiente pois há um grande contingente de famílias que não tem um teto para morar na cidade de Araguaína.

É preciso lembrar que estas moradias foram doadas como forma de compensação pela perda das residências instaladas junto à rodovia TO-222. Na época a Prefeitura, através da sua gestora, a prefeita Valderez Castelo Branco, que governou Araguaína pela primeira vez neste período de 2001-2004, colocava que esta é uma área de risco e que este lugar seria transformado em um parque, um ambiente de lazer, para caminhadas, dentre outros. Hoje o que se vê no lugar é a construção particular de vários empreendimentos comerciais, como já foi relatado aqui. 
Quando indagados sobre o que acham da moradia, no sentido da satisfação de suas necessidades, 38 famílias relataram que a casa é muito pequena, não atendendo, portanto, suas necessidades. Mostraram-se ávidos por realizar uma reforma urgente. Apenas 10 famílias responderam que a casa atende suas necessidades, mas observando o número de compartimentos respondidos por estas famílias, suas moradias já tinham sido reformadas. Pois quando se inquiriu sobre os compartimentos, estas possuam mais de 3 quartos, 2 banheiros ou mais, 2 salas, etc. Evidenciando que a reforma já tinha sido executada. Inferindo-se que antes da reforma, os moradores também não estavam contentes com o tamanho de sua residência. As duas famílias que se mostraram satisfeitas foram aquelas que viviam de aluguel.

Perguntou-se também aos moradores que noção eles têm de uma casa saudável, o que seria isto. A relação de uma casa saudável não está circunscrita, segundo a visão destes entrevistados com a moradia em si, mas com o seu entorno. A casa para ser saudável tem que está associada a um ambiente também saudável. Assim, eles entendem que a casa precisa ter espaços amplos, ser confortável, ser arejada, ter jardim. Mas o lugar também precisa estar arborizado e apresentar uma boa infraestrutura.

A pesquisa também se preocupou em descobrir, dentro desta perspectiva do direito à moradia, o que está representa na vida das pessoas. As respostas convergem para uma premissa, é um bem extremamente valioso. A casa representa o maior bem das suas vidas. Segundo estas famílias o indivíduo em si depende de um ambiente para morar. Quem não tem uma casa segundo os relatos "não tem nada". A casa foi vista como uma questão de segurança, alegria, conquista, satisfação pessoal, dignidade e bem-estar geral.

Aqui é oportuno colocar o pensamento de Gaston Bachelard (1975) em a poética do espaço, quando este autor se refere a casa como um espaço fundamental para a construção do indivíduo, para a formação da sua personalidade. Nela os seres protetores estão presentes, neste núcleo a família se constrói e se molda a formação da sociedade, é aqui o estágio inicial da formação do nosso mundo.

É preciso dizer então como habitamos nosso espaço vital de acordo com todas as dialéticas da vida, como nos enraizamos, dia a dia, num "canto do mundo". Pois a casa é nosso canto do mundo. Ela é como se diz frequentemente, nosso primeiro universo. É um verdadeiro cosmos. Um cosmos em toda a acepção do termo. Até a mais modesta habitação, vista intimamente, é bela. (BACHELARD, 1975, p. 200) 
Quanto às constatações sobre a relação do morador com o bairro o quadro 7 traz informações cruciais que fundamenta nossas análises acerca da infraestrutura e dos equipamentos do mesmo. Já o quadro 7a relata as impressões, os significados da cidade para esses moradores.

Quadro 7: Araguaíana/Jardim das Flores: Questões relativas ao bairro

\begin{tabular}{|c|c|}
\hline \multicolumn{2}{|r|}{ Infraestrutura urbana/políticas públicas/serviços } \\
\hline Água potável & Em todas as moradias constatou-se o fornecimento de água potável. \\
\hline Energia elétrica & A energia elétrica também está presente em todas as residências. \\
\hline Saneamento ambiental & $\begin{array}{l}\text { Não existe rede coletora de esgotos domésticos no bairro. Este fato é } \\
\text { comum a cidade de Araguaína como um todo. }\end{array}$ \\
\hline $\begin{array}{l}\text { Rede de drenagem } \\
\text { urbana }\end{array}$ & Há uma rede de drenagem urbana no bairro. \\
\hline $\begin{array}{l}\text { Estado de conservação } \\
\text { das vias públicas }\end{array}$ & $\begin{array}{c}\text { Para } 64 \% \text { dos entrevistados as vias públicas apresentam bom estado de } \\
\text { conservação. Enquanto isto, } 26 \% \text { responderam que a qualidade das vias } \\
\text { é regular e } 10 \% \text {, consideraram ruim o estado de conservação. }\end{array}$ \\
\hline $\begin{array}{l}\text { Coleta regular de } \\
\text { resíduos sólidos }\end{array}$ & $\begin{array}{l}\text { Para todos os entrevistados a coleta do lixo é satisfatória, pois o carro } \\
\text { passa } 3 \text { vezes por semana. }\end{array}$ \\
\hline Transporte público & $\begin{array}{l}\text { O transporte público foi apontado por } 90 \% \text { dos entrevistados como } \\
\text { problemático, pois não oferece um serviço de qualidade. }\end{array}$ \\
\hline $\begin{array}{l}\text { Posto de atendimento } \\
\text { médico }\end{array}$ & $\begin{array}{l}\text { Há um posto de atendimento médico, mas segundo as famílias } \\
\text { entrevistadas ele funciona precariamente. }\end{array}$ \\
\hline Escola pública & A escola pública foi avaliada como uma instituição de boa qualidade. \\
\hline Creches & $\begin{array}{l}\text { Não foi feito nenhuma reclamação contra a creche, ela atende as } \\
\text { necessidades das famílias. }\end{array}$ \\
\hline $\begin{array}{l}\text { Acessibilidade as } \\
\text { pessoas deficientes }\end{array}$ & $\begin{array}{c}\text { Não há uma estrutura compatível com as necessidades das pessoas } \\
\text { deficientes. }\end{array}$ \\
\hline $\begin{array}{l}\text { Equipamentos de uso } \\
\text { coletivo: praças/parques }\end{array}$ & $\begin{array}{l}\text { Há uma praça no bairro, mas as famílias reclamam da falta de } \\
\text { conservação por parte do poder público. }\end{array}$ \\
\hline Equipamentos culturais & $\begin{array}{l}\text { Há apenas um campo de futebol, que segundo os moradores está quase } \\
\text { sempre fechado para a comunidade. }\end{array}$ \\
\hline Comércio & $\begin{array}{l}\text { Existe uma quantidade significativa de bares e mercearias, e alguns } \\
\text { restaurantes. Mas nas proximidades tem-se posto de combustível e um } \\
\text { supermercado. }\end{array}$ \\
\hline
\end{tabular}

Fonte: Pesquisa empírica realizada por VASCONCELOS FILHO, nos meses de junho, julho e agosto de 2012, no Conjunto Residencial Jardim das Flores, Araguaína-TO. 
Quadro 7.1: Araguaína/Jardim das Flores: Representações urbanas

\begin{tabular}{|c|c|}
\hline $\begin{array}{c}\text { O que você entende por } \\
\text { direito à cidade? }\end{array}$ & $\begin{array}{c}\text { Distintos olhares sobre a cidade } \\
\text { cidade. Já para 62\% dos entrevistados, o direito à cidade está } \\
\text { relacionado ao acesso à educação, saúde e segurança de } \\
\text { qualidade. }\end{array}$ \\
\hline $\begin{array}{c}\text { O que você entende por } \\
\text { cidade saudável? }\end{array}$ & $\begin{array}{c}\text { Para os entrevistados a existência de uma cidade saudável está } \\
\text { associado a saúde da sociedade de uma maneira geral, como } \\
\text { também a limpeza da cidade, coleta do lixo, ar puro e a presença } \\
\text { de uma rede coletora de esgotos domésticos. }\end{array}$ \\
\hline $\begin{array}{c}\text { Na sua opinião o que seria } \\
\text { uma cidade democrática? }\end{array}$ & $\begin{array}{c}\text { As famílias foram categóricas em afirmar que uma cidade para ser } \\
\text { democrática, todos deveriam ter direitos iguais, onde haveria } \\
\text { ainda uma participação mais ativa por parte da sociedade nas } \\
\text { decisões dos gestores. }\end{array}$ \\
\hline $\begin{array}{c}\text { Quais seriam os caminhos } \\
\text { para a construção de cidades } \\
\text { democráticas e saudáveis? }\end{array}$ & $\begin{array}{c}\text { Na maioria das respostas ficou claro que a existência desses } \\
\text { modelos de cidades só será possível quando os gestores } \\
\text { governarem mais numa perspectiva social, preocupando-se mais } \\
\text { com a sociedade e menos com os favores políticos de seus grupos. }\end{array}$ \\
\hline $\begin{array}{c}\text { Na sua opinião, Araguaína } \\
\text { pode ser considerada uma } \\
\text { cidade democrática e } \\
\text { saudável? }\end{array}$ & Nenhuma das famílias entrevistadas considerou Araguaína uma \\
cidade saudável.
\end{tabular}

Fonte: Pesquisa empírica realizada por VASCONCELOS FILHO, nos meses de junho, julho e agosto de 2012, no Conjunto Residencial Jardim das Flores, Araguaína-TO.

No que diz respeito à infraestrutura do bairro e os serviços oferecidos as informações colhidas e registradas através das fotografias demonstram através de uma análise comparativa com outros setores da cidade, que o bairro é bem servido. Embora não se deixe aqui de apontar suas carências urbanas, que fazem parte do conjunto das precariedades urbanas existentes na cidade de Araguaína como um todo. Na verdade, está infraestrutura urbana debilitada marca acentuadamente a paisagem da cidade de Araguaína.

Quanto ao bairro, as famílias demonstraram um elevado grau de satisfação, pois 45 famílias afirmaram que não pretendem sair do Jardim das Flores. Em termos relativos $90 \%$ destas, apontaram itens como segurança, infraestrutura e aprazibilidade como referenciais que justificam seu gosto, pelo lugar.

Como parte desta infraestrutura basicamente tem-se o fornecimento de água potável, energia elétrica e rede drenagem urbana. O esgotamento sanitário não chegou ainda a esta porção da cidade, mesmo porque, que apenas $13 \%$ de toda Araguaína possui saneamento ambiental. 0 estado de conservação das vias públicas foi considerado em boas condições de tráfego para 64\% 
dos entrevistados. Apenas $26 \%$ responderam que as ruas estão em estado regular de conservação e $10 \%$ entenderam que elas estão ruins, que precisam de serviços urgentes de recapeamentos.

No que diz respeito aos serviços oferecidos e os equipamentos que dão suporte a estes serviços. É oportuno salientar que este Residencial já foi entregue com uma considerável rede de serviços essenciais como escola, creche, posto de saúde, associação de moradores. Embora os moradores tenham relatado que o posto de atendimento médico funciona precariamente pela ausência de profissionais da saúde. Já o serviço de coleta de lixo foi apontado como satisfatório, pois regularmente o carro que faz coleta passa 3 vezes por semana (terças-feiras, quintas-feiras e aos sábados.)

No quesito lazer e qualidade ambiental os moradores disseram que há um campo de futebol, mas que este quase sempre está fechado para a comunidade local. Há uma praça que agora se encontra em estágio de degradação. Falta mais espaços para as práticas esportivas de entretenimento, como se observou in loco.

Em todas as famílias entrevistadas a questão sobre a acessibilidade foi dito que o bairro não está preparado para pessoas deficientes, pois a estrutura é precária. Não existe nenhum projeto que garanta a implantação de sinalizadores, rampas e outras necessidades para pessoas deficientes ou aquela com restrição momentânea de acessibilidade. Outro grave problema apontado foi a qualidade dos serviços de transporte público. Principalmente por este demorar muito a passar nos pontos de ônibus que de antemão não são cobertos. Isto faz com que as famílias sejam expostas ao sol ou a chuva.

As questões sobre a cidade estão atreladas as percepções destes moradores no sentido de demonstrarem conhecimento do que consideram o direito à cidade, cidade saudável, cidade democrática e se Araguaína pode ser considerada uma cidade saudável e democrática.

Quanto ao direito a cidade 19 famílias responderam não saber do que se trata. Isto representa 38\% dos entrevistados. Para 62\% dos entrevistados ter direito à cidade está associado a aspectos ligados a políticas públicas, notadamente, a saúde, a educação e segurança. Mas também relacionaram o direito de ir e vir, aos investimentos na cidade pelo pagamento de seus impostos. Além disto evidenciaram que esse direito está ligado a participação do crescimento da cidade.

Ao indagar o que eles entendem por cidade saudável. As respostas em sua quase totalidade referiram-se à saúde da sociedade, a coleta de lixo, a limpeza da cidade e a presença da rede de saneamento básico. Além da necessidade de respirar um ar mais puro. Apesar de Araguaína não contar com um expressivo parque industrial, a poluição do ar deve-se as constantes 
queimadas verificadas durante o inverno, estão mais secas e quentes do ano. Pois os moradores urbanos e também os do campo tem uma cultura de atear fogo seja nos resíduos urbanos, ou nos pastos das fazendas que estão nas cercanias de Araguaína.

Para estas famílias uma cidade democrática seria um modelo de cidade onde todos tivessem os mesmos direitos. Tendo a possibilidade de participar ativamente das decisões que diz respeito aos caminhos pelos quais a cidade deve trilhar com segurança. Incluíram a participação de uma gestão eficiente. Apontaram ainda que a concretização desses modelos de cidades só será possível quando os gestores estiverem mais preocupados com o povo do que com os seus grupos políticos. Isto começaria pelas escolhas que se faz no momento das eleições. Pois este gestor vai representar o povo, portanto, deveria atender suas necessidades.

Assim para isto ser efetivado, seria preciso menos corrupção e uma maior participação popular. Mais de 95\% das famílias afirmaram que Araguaína está muito longe de ser considerada uma cidade democrática e saudável. A paisagem urbana que constatamos testemunha a qualidade do espaço e das moradias que foram construídas para os grupos sociais excluídos. Distantes do centro, com carência de serviços básicos, sem a infraestrutura física adequada, dentre tantos outros problemas que surgem em função desse quadro deteriorado da vida urbana.

\section{CONCLUSÃO}

A realização deste trabalho nos fez perceber que nos setores que abrigam políticas públicas de moradia social, não existe o respeito aos Direitos Humanos, Econômicos, Sociais e Culturais, conforme estabelece a ONU. Pelas observações e entrevistas realizadas, estar-se muito aquém desses direitos. Estas famílias não são de fato atendidas em suas necessidades mais elementares, que por sua vez, se insere no aspecto da qualidade de vida. Se muitas delas, como foram registradas, percebem apenas um salário mínimo, não é difícil deduzir as reais condições de privações pelas quais estas famílias vivem.

Regra geral, se considerar o Programa Minha Casa, Minha Vida, este que mais tem se destacado no âmbito das políticas habitacionais para as camadas sociais de baixa renda, não se tem os parâmetros para uma moradia adequada como a Organização das Nações Unidas, estabelece. Tampouco estamos autorizados a falar de uma cidade que se constrói para ser saudável. Ela não se produz e nem se reproduz com esta finalidade. Este confinamento atribuído as camadas sociais de baixa renda, a um compartimento do espaço urbano, é doentio em todos os 
contextos. Seja sob a perspectiva da privação dos direitos humanos, seja pela perspectiva do aumento da violência urbana em todas as suas formas.

A cidade, sob este ângulo não se torna "doente" apenas para os grupos excluídos, ela está sendo produzida desta maneira para todos. Pois, mesmo aquelas camadas de alta renda, que se confina, se auto segrega em seus condomínios fechados, também são atingidas pelas diversas formas de manifestação da violência urbana. Não há quem escape das consequências de uma "cidade moribunda". Não se remete aqui apenas a doenças do corpo, mas as doenças sociais, produzidas pela lógica perversa deste modo de produção vigente.

Não há programas sociais, sejam de habitação ou não, que deem respostas satisfatórias no sentido de uma ampla transformação do perfil social objetivando solucionar os problemas que se avultam em todos os compartimentos urbanos deste país. Já se pode construir um cenário de que essas políticas públicas habitacionais, tomando esta direção da lógica da acumulação capitalista tendo o espaço urbano como condição está fadada ao fracasso. Araguaína é um bom exemplo dessa situação.

Se pensarmos num outro modelo de cidade e de moradia que contemplem o bem-estar social das pessoas, sem distinções de classe, o caminho não será pelas trilhas da lógica desigual do capital. Se quisermos de fato produzir cidades e moradias saudáveis, este modelo de produção e reprodução do espaço urbano, acompanhado dessas políticas habitacionais que legitimam a segregação e incentiva a especulação imobiliária, não trará os reais benefícios que a sociedade deseja e necessita. As políticas de moradia social e outras que se inserem no espaço urbano deverão contemplar primordialmente as pessoas. São estas que dão vida e dinamizam este espaço, sem considerá-la mais ou menos importante, em função da sua classe social.

Considerando os parâmetros colocados pela Organização das Nações Unidas, nenhum dos setores visitados em Araguaína preenchem os pré-requisitos para afirmarmos que as moradias são de fato adequadas quanto as necessidades das famílias que ali residem. Estabelecendo como referencial a estrutura física urbana desses setores, com algumas exceções, com destaque para o Conjunto Residencial Jardim das Flores, o Vila Azul e o Residencial Patrocínio, os demais apresentam uma precariedade bastante acentuada nesse aspecto. O aumento da produção de moradias motivado pelo "Programa Minha Casa Minha Vida", e a lógica capitalista de reprodução do capital imobiliário no espaço urbano de Araguaína continuam o mesmo. Assimilado pelo capital como mercadoria, o espaço urbano e a cidade como um todo reproduzem as distinções de classes sociais. 
Ao implantar políticas públicas de moradia social para as camadas de baixa renda, esta que sustenta mais de $80 \%$ do déficit habitacional no território brasileiro como um todo, o Estado em comum acordo com o capital, consegue manter e aprofundar a desigualdade social.

Esta lógica se reproduz em todas as porções do espaço urbano brasileiro e diríamos que em Araguaína, ela se instalou de maneira mais profunda. Podemos apontar ainda estes problemas para os novos programas habitacionais que serão entregues em breve aos grupos sociais de baixa renda. Destacamos o Residencial Costa Esmeralda I e II e Residencial Boa Vista. Estes empreendimentos estão a cerca de $5 \mathrm{~km}$ da Área Central da cidade. Se considerarmos a má qualidade de serviço de transporte público, realizado em regime de monopólio por uma empresa desta cidade, já dar para se ter uma ideia do quanto essa sociedade vai perecer.

Como se percebe não basta aumentar a oferta de moradias para sanar o déficit habitacional, acreditando com isto que o problema foi resolvido. Jogar esses grupos vulneráveis nas extremidades da cidade é privá-los dos seus direitos básicos, significa ao mesmo tempo criar as condições necessárias para um aumento dos processos de segregação espacial, de especulação imobiliária, tendo como consequência a ampliação e concentração do capital que usa o espaço como condição para as suas ações. Assim, expulsam esses moradores para espaços cada vez mais distantes da cidade e ao mesmo tempo cria-se também a estratégia da escassez da terra urbana proporcionado pelos novos "vazios urbanos", ou áreas intermitentes do espaço que posteriormente serão ocupados, após a instalação de alguma política pública.

Ao relacionar a terra urbana e a moradia enquanto valor de troca, ou seja, mercadorias legitima-se ao tempo que se faz perpetuar a valorização das camadas de alta renda, em detrimento daqueles que vivem nas áreas mais decadentes da cidade. O Estado Capitalista, torna desse modo, permanente a visão exploradora de uma classe em relação à outra. Assim engessa-se um quadro de miséria e pobreza que se perpetua há séculos em nosso território.

\section{REFERÊNCIAS BIBLIOGRÁFICAS}

BACHELAR, G. A poética do Espaço. São Paulo: Civita, 1975.

CARTA DE OTTAWA. Primeira Conferência Internacional sobre Promoção da Saúde. Ottawa, Canadá, 1986. Disponível em www.bvms.saude.gov.br, Acessado em fevereiro de 2011.

CORRÊA, R. L. Construindo o conceito de cidade média. In: SPÓSITO, Maria Encarnação B. (Org.) Cidades Médias: Espaços em transição. São Paulo: Expressão Popular, 2007. 
FUNDAÇÃO JOÃO PINHEIRO. Centro de Estatística e Informações. Déficit Habitacional no Brasil. 2. ed. Belo Horizonte: 2005.

KROLL, V. Fórum dos Cortiços, São Paulo, 2004

MARICATO, E. Política urbana e de habitação social: um assunto pouco importante para o governo FHC. Disponível em: www.usp.br/fau. Acessado em: 19/10/2010.

MARICATO, E. Cidades-Urgentes: colocar a questão urbana na agenda nacional. In: Revista Carta Maior. 08 de junho de 2012. Disponível em: www.cartamaior.com.br, acessado em 16/03/2013.

MARTINS, J. de S. Exclusão social e a nova desigualdade. São Paulo: Paulus, 1997.

MARX, K. Contribuição à crítica da economia política. Tradução de Maria Helena Barreiro Alves. São Paulo: Martins Fontes, 1977.

O capital: Crítica da economia política: livro I. Tradução de Reginaldo Sant'Anna. 22a ed. Rio de Janeiro: Civilização Brasileira, 2008.

MENDES, R.. \& WESTPHAL, M. F. Cidade Saudável: Uma experiência de interdisciplinaridade e intersetorialidade. In: Revista de Administração Pública - RAP, Fundação Getúlio Vargas - FGV. 34 (6): 47-61, Rio de Janeiro. Novembro/Dezembro de 2000.

PINHO, M. J. De Província de Goiás a estado do Tocantins: o camponês do Bico do Papagaio e o conflito da terra na década de 1980. In: FIRMINO, Eugênio Pacelli de Morais. Org. Tocantins: do passado (re) construído e do presente em construção - História, Escola, Universidade e Conhecimento. Goiânia: Ed. UCG, 2009.

ROLNIK, R. \& SAULE JÚNIOR, N. Estatuto da cidade: Novas perspectivas para a reforma urbana. São Paulo: Polis, 2001.

ROUSSEAU. Jean-Jacques. Discurso sobre a origem e os fundamentos da desigualdade entre os homens. Tradução Alex Marins. São Paulo: Martin Claret, 2007.

SANTOS, M. A urbanização brasileira. São Paulo: Hucitec, 1993.

Metamorfoses do espaço habitado. 5. ed. São Paulo: Hucitec, 1993.

SAULE JUNIOR, N. \& ROLNIK, R. Estatuto da Cidade: Novas perspectivas para a reforma urbana. São Paulo: Polis, 2001.

SAULE JUNIOR, N. \& CARDOSO, P. M. O direito à moradia no Brasil: violações, práticas positivas e recomendações ao governo brasileiro - Relatório da Missão Conjunta da Relatoria Nacional e da ONU/29/05 a 12/06 de 2004. São Paulo: Instituto Pólis, 2005.

TOCANTINS. PLANO DIRETOR DA CIDADE DE ARAGUAÍNA. Araguaína-TO, 2004.

Trabalho enviado em 08 de julho de 2015.

Aceito em 28 de outubro de 2015. 